\title{
Low-wage careers: Are there dead-end firms and dead-end jobs?
}

\author{
Alexander Mosthaf · Claus Schnabel · Jens Stephani
}

Accepted: 8 July 2010 / Published online: 18 August 2010

(C) Institut für Arbeitsmarkt- und Berufsforschung 2010

\begin{abstract}
Using representative linked employer-employee data of the German Federal Employment Agency, this paper shows that just one out of seven full-time employees who earned low wages (i.e., less than two-thirds of the median wage) in 1998/99 was able to earn wages above the lowwage threshold in 2003. Bivariate probit estimations with endogenous selection indicate that upward wage mobility is higher for younger and better qualified low-wage earners, whereas women are substantially less successful. We show that the characteristics of the employing firm also matter for low-wage earners' probability of escaping low-paid work. In particular, small plants and plants with a high share of low-wage earners often seem to be dead ends for low-wage earners. The likelihood of leaving the low-wage sector is also low when staying in unskilled and skilled service occupations and in unskilled commercial and administrative occupations. Consequently, leaving these dead-end plants and occupations appears to be an important instrument for achieving wages above the low-wage threshold.
\end{abstract}

Keywords Low-wage employment · Wage mobility · Germany

JEL classification J30 - J60

\section{Niedriglohnkarrieren: Werden bestimmte Betriebe oder Beschäftigungen zur Sackgasse?}

Zusammenfassung Mit repräsentativen, verbundenen $\mathrm{Ar}$ beitgeber-Arbeitnehmer-Daten der Bundesagentur für Arbeit verdeutlicht diese Studie, dass nur jeder siebte Vollzeitbeschäftigte, der 1998/99 einen Niedriglohn (von weniger als zwei Dritteln des Medianlohns) bezog, bis 2003 den Niedriglohnsektor verlassen konnte. Bivariate Probit-Schätzungen mit endogener Selektion deuten darauf hin, dass die Aufwärtsmobilität für jüngere und besser qualifizierte Geringverdiener höher ausfällt, wohingegen Frauen deutlich weniger erfolgreich sind. Wir zeigen, dass auch die Merkmale des Beschäftigungsbetriebes die Aufstiegswahrscheinlichkeit beeinflussen. Insbesondere kleinere Betriebe und solche mit einem hohen Anteil von Niedriglohnbeschäftigten scheinen häufig Sackgassen für Geringverdiener darzustellen. Die Wahrscheinlichkeit, den Niedriglohnsektor zu verlassen, ist ferner relativ gering, wenn man in bestimmten (meist weniger qualifizierten) Jobs verharrt. Die Abwanderung aus solchen Betrieben und Beschäftigungen, die Sackgassen darstellen, dürfte deshalb ein wichtiges Mittel sein, um höhere Löhne zu erzielen.

\section{Introduction}

Since the 1990s, the low-wage sector has expanded considerably in Germany (Rhein and Stamm 2006; Bosch and Kalina 2008). In 2005 about $18 \%$ of full-time employees covered by social insurance earned wages that amounted to less than two-thirds of the median wage, and they were thus regarded as low-wage earners (Rhein and Grün 2007). While such a large share of low-wage workers may be a cause of concern on its own, for an accurate interpretation of this phe- 
nomenon it is important to know whether low-wage employment is a transitory or a persistent experience of individuals in their working careers. Put differently, are low-wage jobs mainly stepping stones to better-paid jobs or are lowwage careers the norm where employees in the low-wage sector have limited chances of upward mobility? If the latter is the case, can we identify individual characteristics or obstacles in the working environment that hinder employees from leaving the low-wage sector?

The upward mobility of low-wage earners has been analyzed in a number of international studies for OECD countries and for Germany. ${ }^{1}$ Most of these studies find that upward wage mobility differs among employees, with certain groups such as female and older workers having lower chances of reaching higher-paid jobs. While these and other individual determinants of upward mobility have been investigated in many studies, due to a lack of data relatively few studies have been able to analyze the impact of firm and workplace characteristics on employees' chance of escaping low-paid work. To be sure, a few studies exist that point to the relevance of the size and sector affiliation of a firm for employees' upward wage mobility (see, e.g., Stewart and Swaffield 1999; Cappellari 2002; Andersson et al. 2005). For Germany, Schank et al. (2009) recently have shown that low-wage employment is concentrated (and upward wage mobility is lower) in small firms and in certain industries. With Danish data, Bolvig (2005) has demonstrated that the characteristics of the employing firm matters for low-wage employees' likelihood of escaping a low-wage job, and she has been able to identify three types of firms: firms with high within-firm upward wage mobility, firms with high betweenfirm upward wage mobility (i.e. stepping-stones) and firms with low upward wage mobility (i.e. dead-end firms).

This paper adds to the literature by paying special attention to the role of the plants and jobs in which low-wage earners are employed. Taking account of labour market segregation (i.e. that low-wage earners, foreigners, and women may be concentrated in certain firms), we investigate whether there do indeed exist dead-end firms and dead-end jobs where workers have very low chances of escaping low-wage employment. We also explore whether changing firms and/or jobs is a promising means of obtaining higher pay. Using representative linked employer-employee data of the German Federal Employment Agency, we analyze the

\footnotetext{
${ }^{1}$ See, for instance, the cross-country studies by OECD (1996), Asplund et al. (1998), and European Commission (2004). Country-specific analyses are provided, inter alia, by Andersson et al. (2005) for the US, Stewart and Swaffield (1999) and Cappellari and Jenkins (2008) for the UK, Bolvig (2005) for Denmark, Cappellari (2002) and Cappellari (2007) for Italy, and Eichhorst et al. (2005), Uhlendorff (2006) and Schank et al. (2009) for Germany. Deding (2002) compares low-wage mobility in Germany, Denmark and the US, while Grün et al. (2009) provide evidence from administrative data in Germany and Austria.
}

wage and employment careers of full-time employees who earned low wages in 1998/1999. We follow this cohort over time and show to what extent these low-wage workers were able to earn higher wages in the following years and which individual, plant or occupational characteristics played a role in this context.

The paper is organized as follows: After a description of our data set in Sect. 2, some research questions and hypotheses are identified (Sect. 3). Section 4 presents some descriptive evidence, while the results of our econometric analysis are discussed in Sect. 5. Section 6 concludes.

\section{The data}

In order to be able to investigate the role of both individual and plant-level characteristics for upward wage mobility, we make use of the weakly anonymous version of the Employment Panel of the Federal Employment Agency (BAP). This administrative data set is a representative $2 \%$ random sample of German workers liable to social security drawn from the notifications of employment to the social security bodies (Koch and Meinken 2004; Schmucker and Seth 2006). Besides individual characteristics, the quarterly panel also includes detailed information about plants. The data set is available at the Research Data Centre (FDZ) of the German Federal Employment Agency (BA) at the Institute for Employment Research (IAB). For our analyses we linked additional data stemming from the IAB Employment History and the Integrated Employment Biographies of the IAB (IEB) as well as data collected by the Federal Employment Agency. ${ }^{2}$

In accordance with a number of international studies, we define an individual as being low-paid if he or she earns less than two thirds of the median monthly gross wage of full-time employees. ${ }^{3}$ We take into account that wages in eastern Germany are markedly lower and that the eastern German wage distribution lies to the left of the western German one, which can be seen in the kernel density estimations for 1998 and 2003 presented in Figs. 1 and $2 .^{4}$ This

\footnotetext{
${ }^{2}$ These additional variables are: low-wage employment in 1997, part-time employment in 1997, years of work between 1993 and 1997, percentage of low-wage workers in the plant, percentage of foreign workers in the plant, regional unemployment rate (at district level) in June 1997.

${ }^{3}$ While this definition is somewhat arbitrary, it has become a sort of benchmark in most international studies. Alternatively we could have used other relative or absolute measures of low pay (such as deciles of the wage distribution or monthly earnings below $1200 €$ ); see Sloane and Theodosssiou (1998) for a discussion of methodological issues. Interestingly, Eichhorst et al. (2005) demonstrate that the structure and development of the lowwage sector is relatively insensitive to varying the low-pay threshold.

${ }^{4}$ Note that these kernel density estimations are based on the sample of fulltime employees used in the following empirical analysis. Wages are right censored at about the contribution assessment ceiling and left censored by the exclusion of individuals with implausible information on wages (see footnote 5).
} 


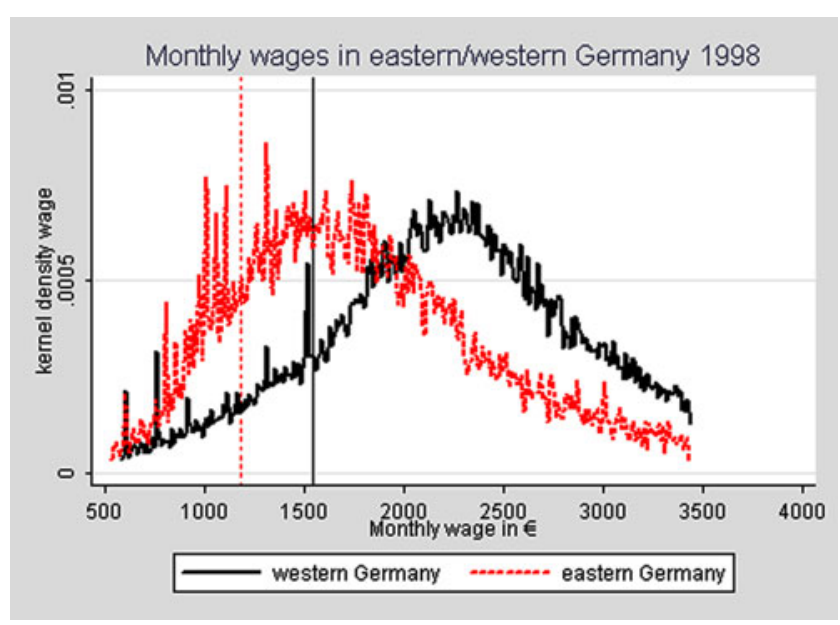

Fig. 1 Wage distributions in western and eastern Germany in 1998. Note: Vertical lines indicate low-wage thresholds. Wages are right censored at the contribution assessment ceiling

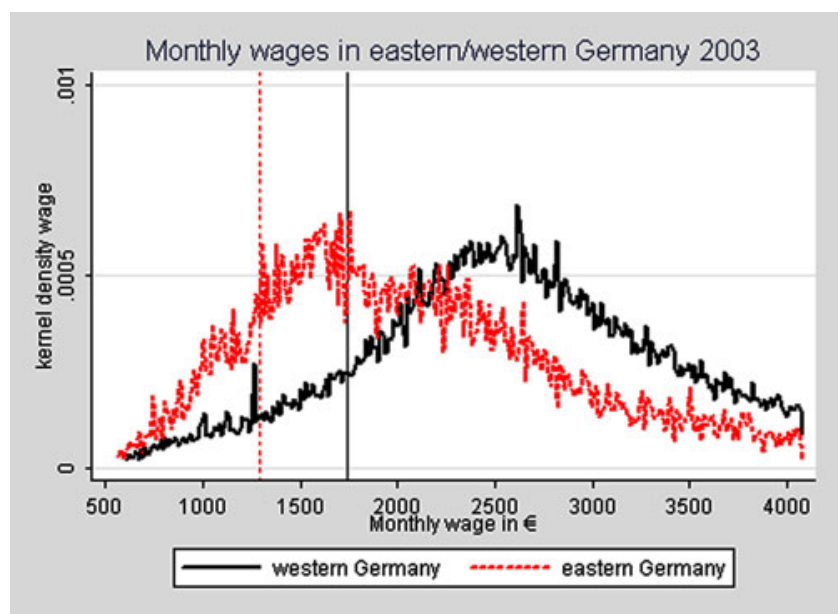

Fig. 2 Wage distributions in western and eastern Germany in 2003. Note: Vertical lines indicate low-wage thresholds. Wages are right censored at the contribution assessment ceiling

is partly due to the fact that in eastern Germany fewer firms are covered by collective agreements and even if they are covered they less often pay wages above the level stipulated in these agreements than do western German firms (see Görzig et al. 2004; Jung and Schnabel 2009). In order to deal with the wage differential between eastern and western Germany, which might bias our results, we calculate the low-wage threshold separately for these two parts of the country. We obtain low-wage thresholds that lie between $1546 €$ and $1740 €$ in western Germany and between $1179 €$ and $1293 €$ in eastern Germany in the years 1998 to 2003.

In our analysis we focus on workers whose wages were below the low-wage threshold both in 1998 and in 1999. By doing so we hope to make sure that the individuals we are studying are indeed "true" low-wage workers and not indi- viduals who occupied a low-wage job for only a short time. This could be the case, for example, if a person knows in advance that she will start a high-paid job in the future and takes up a low-paid job only to bridge the time gap. We observe this cohort of low-wage workers in 1998/99 until the year 2003 and investigate whether they are able to cross the respective low-wage thresholds in 2000 and 2003.

For various reasons we restrict our analysis to full-time employees. We thus avoid the problem that some part-time employees may have chosen their (often low-paid) job voluntarily, for example women engaged in childcare or students. Moreover, precise working hours of part-time workers are not available in our data set (there are just two crude categories: part-time work in general and part-time work with less than 18 working hours), which would make it extremely difficult to classify them as low-paid or high-paid. To focus on the core group of the labour market and to minimize transitions into retirement, we exclude trainees, interns, working students, retired persons and persons younger than 15 or older than 57 years in 1998. Furthermore, we do not consider observations with implausible information on wages. ${ }^{5}$ Since our administrative dataset is highly reliable, this problem affects only about $4 \%$ of full-time employees.

The resulting sample covers 241,742 individuals, with 28,184 of these being low-wage earners both in 1998 and 1999. We analyze their transitions from 1999 to 2000 and from 1999 to 2003 and use information from the second quarter (i.e. the BAP-cross-sections at June 30) of each year.

\section{Research questions and hypotheses}

The data described above enable us to investigate the role of three factors that may be relevant for the upward mobility of low-wage earners: individual characteristics, establishment characteristics and occupational characteristics. While the main focus of this paper is on the latter two factors and on the identification of dead-end firms or dead-end jobs, individual characteristics must also be taken into account.

In previous studies with German data, individual characteristics such as sex, age, and education have been found to significantly affect employees' likelihood of escaping the low-wage sector (see Eichhorst et al. 2005; Schank et al. 2009). We are able to include information on employees' sex, age, formal qualification and (non-German) nationality in our analyses. In accordance with the extant evidence

${ }^{5}$ We excluded individuals earning less than $602 €(3.5 € \times 40 \mathrm{~h} \times$ 4.3 weeks $)$ in eastern Germany and less than $645 €(4 € \times 40 \mathrm{~h} \times$ 4.3 weeks) in western Germany (in prices of 2006). In addition, we did not analyze individuals with high-qualification occupations such as managers or engineers who were earning a low wage while being employed full-time. Such presumably wrong information could emerge if an individual who works part-time is incorrectly registered as a full-time employee. 
and with theoretical considerations from human capital and search theory, we expect that upward mobility is higher for younger workers who might not yet have found an optimal job-match and for low-wage earners with higher formal qualifications due to their higher general human capital and productivity potential. In contrast, upward wage mobility can be expected to be lower for women due to interruptions in their working career (and the loss of human capital and the "statistical discrimination" that often go with it) as well as for low-wage earners with non-German nationality who may suffer from language barriers and labour market discrimination. The theoretical background of these explanatory variables is discussed in more detail in the companion paper by Schank et al. (2009). For an exposition of human capital and search theory, see Cahuc and Zylberberg (2004, Chap. 2 and 3). There is also a theoretical and empirical literature showing that less qualified workers find it harder to work their way up the wage distribution due to higher search frictions. Accordingly, employers have more market power over these employees and may therefore have an incentive to pay lower wages to these workers (see, e.g., Postel-Vinay and Robin 2002; Manning 2003, pp. 44-49).

Taking these individual characteristics as a sort of control variables, we now concentrate on identifying establishment or occupational characteristics that may be detrimental to the upward wage mobility of low-wage earners. One likely suspect for creating dead ends in wage mobility is firm size, which already has been shown to play a role in a previous study for Germany (Schank et al. 2009). In Germany, larger firms more frequently offer further training and other chances of human capital accumulation than smaller firms (Gerner and Stegmaier 2008), and they also more often have internal labour markets with hierarchical wages and chances of transition along well-defined job ladders (Klein-Schneider 2003). This implies that the upward wage mobility of low-wage earners may be significantly lower in smaller establishments.

Upward mobility could also be affected by the workforce composition in the establishment. A high share of qualified employees, for instance, may indicate that this is a firm in which human resources development is important (and thus upward mobility easier), whereas a high share of older employees could suggest that the workforce and the internal structures of the firm are less flexible and upward mobility thus more difficult (see Nienhüser 1998). More importantly, labour market segregation could also play a role. Low-wage earners may be concentrated in establishments where a large share of employees are paid low wages (Bolvig 2005), so that we would expect upward mobility of individual lowwage earners to be lower if working in such an establishment. Similarly, the chances of leaving the low-wage sector may be lower for women employed in establishments with a predominantly female workforce, be it due to gender- based segregation, discrimination or just low-cost strategies in such firms (Pfeffer and Davis-Blake 1987; Achatz et al. 2005). The same applies to foreigners working in establishments with a high share of foreign employees. Our data will enable us to test whether these sorts of firms are really dead ends for specific (low-paid) employees.

In addition to dead-end firms, there may also exist certain occupations or jobs that are more likely than others to be dead ends. While it is difficult to set up clear hypotheses here, it could be expected, for instance, that in unskilled occupations the chances of leaving the low-wage sector may be lower than in skilled occupations and in semi-professions. In our data we have information on the type of occupation in which an employee is working, which is categorized according to a classification by Blossfeld (1987). Since this classification is a little bit dated and since it is not clear how accurately employers categorize their employees, we use only eight broad categories of occupations (ranging from unskilled manual over skilled services to semi-professions such as nurses, social workers and interpreters), so the results of this investigation must be taken with a pinch of salt. Nevertheless it may be interesting to see whether there are differences in upward wage mobility among occupations.

Finally, it is important to know how employees can escape from the low-wage sector. More specifically, although job mobility is to a certain degree endogenous (i.e. mainly driven by aspirations to improve one's position), we would like to see whether moving to another firm (as suggested by Andersson et al. 2005) or to another occupation is a successful strategy for leaving low-paid employment. In particular, if the employee is working in a dead-end firm and/or in a dead-end job with no chances of upward wage mobility, leaving this firm and/or job may be her only way to escape the low-wage trap. ${ }^{6}$ Given the limited chances of upward wage mobility in small firms discussed above and assuming that small firms are more likely to promote general skills whereas large firms are more likely to generate specific skills (Bolvig 2005), we would expect that leaving small firms should be particularly promising, whereas leaving large firms may not be so beneficial. A more technical argument would be that individuals in small firms can move to larger, and thus better-paying, firms whereas individuals in the group of largest firms cannot. We also expect that transitions into higher-paid employment are more likely if individuals leave plants that have a large share of low-paid workers. Similarly, although we do not have specific hypotheses here,

\footnotetext{
${ }^{6}$ While this is the case for voluntary moves which may reflect that individuals have found a better-paid job, involuntary moves (due to lay-offs, and perhaps associated with temporary unemployment and loss of human capital) could of course also result in lower chances of upward wage mobility. Unfortunately, we are not able to distinguish between voluntary and involuntary separations in our data set.
} 
we will check whether there are occupations where moving out is particularly important and successful. ${ }^{7}$

In addition to the individual, plant-level and occupational characteristics discussed above, further factors that might play a role for upward wage mobility should be taken into account, even if there exist no clear-cut hypotheses here. For instance, industries differ in a number of difficult-to-observe variables such as the existence of internal labour markets, personnel policies, hierarchies, production processes and traditions that may facilitate or hamper upward mobility. Due to the substantially different labour market situation in western and eastern Germany, in which of these regions a plant is located may also be important for leaving the low-wage sector. In the econometric investigation in Sect. 5 we will therefore control for industry affiliation and for location in eastern Germany and see whether these factors are associated with upward wage mobility.

\section{Descriptive evidence}

Table 1 presents some information on our sample of low-wage earners based on the representative BA Employment Panel. Recall that we focus only on those full-time employees earning less than two-thirds of the median wage in two subsequent years (1998/99). It can be seen that this group of (true or multi-year) low-wage earners consists predominantly of women and of employees who have lower levels of formal education or are in unskilled occupations. Interestingly, they are concentrated in smaller plants and in plants that have a high percentage of low-paid workers, which points to the relevance of establishment characteristics suggested above.

In Table 2 it is shown which labour market status individuals who were full-time low-wage earners in 1998/99 reach in the following years. Within one year (i.e. until 2000), about $9 \%$ of these individuals manage to leave low-paid employment whereas $73 \%$ stay in the low-wage sector (which means that they earn less than two-thirds of the new median wage in 2000). After four years (i.e. in 2003), more than $15 \%$ of the low-wage earners have moved into higherpaid employment, and only $45 \%$ have remained in low-paid full-time employment. About $10 \%$ have taken up part-time or marginal employment and about $9 \%$ are not employed anymore. For roughly $20 \%$ of our sample we have no information on their labour market status in 2003 - they may

\footnotetext{
${ }^{7}$ Since our focus in this paper is on identifying dead-end firms and occupations, we take into account only the characteristics of the plants and occupations in which individuals are currently employed (and which they leave) but do not investigate into which plants and occupations they move. Such transition matrices between current and future plants and occupations might be interesting, but their implementation in the estimations and their interpretation would be difficult.
}

Table 1 Composition of the low-wage worker group in the BA Employment Panel (BAP)

\begin{tabular}{|c|c|}
\hline & $\begin{array}{l}\text { Low-wage } \\
\text { workers } \\
(1998 / 99)\end{array}$ \\
\hline Number of observations & 28,184 \\
\hline \multicolumn{2}{|l|}{ Sex } \\
\hline Men & $27.22 \%$ \\
\hline Women & $72.78 \%$ \\
\hline \multicolumn{2}{|l|}{ Age (years) } \\
\hline $15-24$ & $13.80 \%$ \\
\hline $25-34$ & $27.66 \%$ \\
\hline $35-49$ & $43.37 \%$ \\
\hline $50-57$ & $15.17 \%$ \\
\hline \multicolumn{2}{|l|}{ Level of education } \\
\hline School leaving certificate without vocational training & $19.17 \%$ \\
\hline Secondary school certificate with vocational training & $61.39 \%$ \\
\hline High school certificate with vocational training & $1.25 \%$ \\
\hline University degree & $0.64 \%$ \\
\hline Unknown & $17.56 \%$ \\
\hline \multicolumn{2}{|l|}{ Type of occupation } \\
\hline Unskilled manual occupations & $18.85 \%$ \\
\hline Skilled manual occupations & $12.49 \%$ \\
\hline Unskilled services & $20.93 \%$ \\
\hline Skilled services & $12.95 \%$ \\
\hline Unskilled commercial and administrative occupations & $15.53 \%$ \\
\hline Skilled commercial and administrative occupations & $16.62 \%$ \\
\hline Semi-professions & $2.28 \%$ \\
\hline Unknown & $0.33 \%$ \\
\hline \multicolumn{2}{|l|}{ Nationality } \\
\hline German & $90.03 \%$ \\
\hline Foreign & $9.97 \%$ \\
\hline \multicolumn{2}{|l|}{ Region } \\
\hline Western Germany & $76.81 \%$ \\
\hline Eastern Germany & $23.19 \%$ \\
\hline \multicolumn{2}{|l|}{ Plant size } \\
\hline 1-20 employees & $58.43 \%$ \\
\hline 21-100 employees & $24.91 \%$ \\
\hline 101-500 employees & $13.72 \%$ \\
\hline More than 500 employees & $2.93 \%$ \\
\hline \multicolumn{2}{|l|}{ Share of low-paid workers in the plant } \\
\hline Less than $5 \%$ & $3.39 \%$ \\
\hline $5-39 \%$ & $22.32 \%$ \\
\hline $40-79 \%$ & $34.27 \%$ \\
\hline $80-100 \%$ & $39.70 \%$ \\
\hline Unknown & $0.32 \%$ \\
\hline
\end{tabular}

Note: Low-wage workers are defined as full-time employees earning less than two-thirds of the median wage in two subsequent years (1998/99).

Source: own calculations based on BAP.

have (temporarily or permanently) left the labour market, could have become self-employed, etc. Since some of these persons might have been able to leave the low-wage sector by taking up more lucrative self-employment, the true chance of upward mobility may be higher than the $15 \%$ 
Table 2 Labour market status of the low-wage workers from 1998/99 in later years

\begin{tabular}{llllll}
\hline Status & $\begin{array}{l}\text { Low-wage } \\
\text { employment }\end{array}$ & $\begin{array}{l}\text { Higher-wage } \\
\text { employment }\end{array}$ & $\begin{array}{l}\text { Part-time/ } \\
\text { marginal } \\
\text { employment }\end{array}$ & $\begin{array}{l}\text { Not } \\
\text { employed }\end{array}$ & $\begin{array}{l}\text { No } \\
\text { information }\end{array}$ \\
Year & $73.04 \%$ & $8.77 \%$ & $3.64 \%$ & $5.20 \%$ & $9.36 \%$ \\
2000 & $45.11 \%$ & $15.20 \%$ & $10.18 \%$ & $9.27 \%$ & $20.24 \%$ \\
\hline
\end{tabular}

Source: own calculations based on BAP.

\begin{tabular}{|c|c|c|c|}
\hline & $\begin{array}{l}\text { Obser- } \\
\text { vations }\end{array}$ & $\begin{array}{l}\text { Low-wage } \\
\text { employment } \\
(\%)\end{array}$ & $\begin{array}{l}\text { Higher-wage } \\
\text { employment } \\
(\%)\end{array}$ \\
\hline Total & 16,998 & 74.80 & 25.20 \\
\hline \multicolumn{4}{|l|}{ Sex } \\
\hline Men & 4,694 & 62.72 & 37.28 \\
\hline Women & 12,304 & 79.41 & 20.59 \\
\hline \multicolumn{4}{|l|}{ Age (years) } \\
\hline $15-24$ & 2,291 & 53.69 & 46.31 \\
\hline $25-34$ & 4,507 & 67.16 & 32.84 \\
\hline $35-49$ & 7,960 & 81.31 & 18.69 \\
\hline $50-57$ & 2,240 & 88.66 & 11.34 \\
\hline \multicolumn{4}{|l|}{ Level of education } \\
\hline School leaving certificate without voc. training & 3,171 & 77.14 & 22.86 \\
\hline Secondary school certificate with voc. training & 10,669 & 74.28 & 25.72 \\
\hline High school certificate with vocational training & 220 & 63.18 & 36.82 \\
\hline University degree & 113 & 68.14 & 31.86 \\
\hline Unknown & 2,825 & 75.33 & 24.67 \\
\hline \multicolumn{4}{|l|}{ Type of occupation } \\
\hline Unskilled manual occupations & 3,265 & 74.52 & 25.48 \\
\hline Skilled manual occupations & 2,132 & 70.36 & 29.64 \\
\hline Unskilled services & 3,477 & 77.11 & 22.89 \\
\hline Skilled services & 2,287 & 77.04 & 22.96 \\
\hline Unskilled commercial and administrative occ. & 2,518 & 81.57 & 18.43 \\
\hline Skilled commercial and administrative occ. & 2,293 & 69.04 & 30.96 \\
\hline Semi-professions & 347 & 67.44 & 32.56 \\
\hline Unknown & 49 & 67.35 & 32.65 \\
\hline \multicolumn{4}{|l|}{ Nationality } \\
\hline German & 15,572 & 75.25 & 24.75 \\
\hline Foreign & 1,426 & 69.85 & 30.15 \\
\hline \multicolumn{4}{|l|}{ Region } \\
\hline Western Germany & 13,006 & 74.11 & 25.89 \\
\hline Eastern Germany & 3,992 & 77.05 & 22.95 \\
\hline \multicolumn{4}{|l|}{ Plant size } \\
\hline 1-20 employees & 9,923 & 77.31 & 22.69 \\
\hline 21-100 employees & 4,319 & 73.44 & 26.56 \\
\hline $101-500$ employees & 2,291 & 69.01 & 30.99 \\
\hline More than 500 employees & 465 & 62.58 & 37.42 \\
\hline \multicolumn{4}{|l|}{ Share of low-paid workers in the plant } \\
\hline Less than $5 \%$ & 421 & 60.57 & 39.43 \\
\hline $5-39 \%$ & 3,948 & 66.39 & 33.61 \\
\hline $40-79 \%$ & 6,017 & 76.30 & 23.70 \\
\hline $80-100 \%$ & 6,584 & 79.42 & 20.58 \\
\hline Unknown & 28 & 67.86 & 32.14 \\
\hline
\end{tabular}

Note: The personal and plant-level characteristics shown are from 1999. Source: own calculations based on BAP. 
identified above. Nevertheless, since only about one in seven low-wage earners manages to reach higher-paid (dependent) employment within four years, upward wage mobility seems to be rather limited on average.

The upward mobility of those low-paid workers from 1998/99 who were still in full-time employment in 2003 is presented in Table 3 (results for 2000 point in the same direction and are available on request). In this sub-sample, about $25 \%$ of low-wage earners are able to reach higherpaid employment by 2003. Table 3 makes clear, however, that the chances of leaving low-paid work differ substantially between groups of workers, occupations and plants. Consistent with previous studies for Germany that mainly focused on individual characteristics, upward wage mobility is lower for older employees, for employees with low levels of qualification and for women. It is striking that more than $37 \%$ of men, but less than $21 \%$ of women are able to leave the low-wage sector within four years. Somewhat unexpectedly, foreigners show a higher upward mobility than Germans, which may reflect a positive selection effect since foreigners are less frequent in this sub-sample of full-time employees.

Upward wage mobility is about the same in western and eastern Germany, and it is particularly high in some skilled occupations and in semi-professions. Concerning plant-level characteristics it is obvious that employees in larger plants and in plants with a low share of low-paid workers are more often able to leave low-paid employment. Put differently, in accordance with expectations there is some descriptive evidence that small plants and plants with a high share of lowpaid workers might be dead ends for many low-wage earners. It will be interesting to see whether this is confirmed in the following multivariate analysis.

\section{Econometric analysis}

In the econometric analysis we study the probability of a full-time low-wage earner (in 1998/99) reaching higherpaid full-time work in 2000 or 2003 and the factors associated with such upward wage mobility. In this context it is important to avoid an initial conditions and sample selectivity problem (Heckman 1981) by taking into account that individuals' low-wage status in 1998/99 may be not be exogenous. Following Stewart and Swaffield (1999) and Schank et al. (2009), we therefore estimate a bivariate probit model with endogenous selection which takes account of the probability of being low-paid in 1998/99 as well as the conditional probability of leaving this status by 2003 . In a likelihood function we include both the determinants of the initial low-wage status (selection equation) and the factors associated with escaping from low-paid work (upward mobility equation).
Let $y_{i 0}$ be a dummy variable which is 1 if an individual is low-paid in 1998/99:

$$
P\left(y_{i 0}=1\right)=P\left(y_{i 0}^{*}=g\left(z_{i} \gamma^{*}+\varepsilon_{i 0}\right)<\kappa\right)=\Phi\left(z_{i} \gamma\right),
$$

where $y_{i 0}^{*}$ represents the underlying latent variable and $\kappa$ is the low-wage threshold. $\Phi$ denotes the cumulative standard normal distribution. This yields a probit model for the probability of being low-paid in 1998/99 (selection equation).

Let $y_{i 1}$ then be a dummy variable which is 1 if a lowwage worker has reached high-paid employment in the year 2000 or 2003 :

$$
P\left(y_{i 1}=1\right)=P\left(y_{i 1}^{*}=f\left(x_{i} \beta^{*}+\varepsilon_{i 1}\right)>\kappa\right) .
$$

The error terms $\left(\varepsilon_{i 0}, \varepsilon_{i 1}\right)$ are assumed to follow a bivariate standard normal distribution with correlation $\rho$.

Therefore, the conditional probability that an initially low-paid individual climbs up the wage ladder to a higher-paid job is given by

$$
P\left(y_{i 1}=1 \mid y_{i 0}=1\right)=\frac{\Phi_{2}\left(x_{t} \beta, z_{i} \gamma, \rho\right)}{\Phi\left(z_{i} \gamma\right)},
$$

where $\Phi_{2}$ denotes the cumulative bivariate standard normal distribution.

The correlation $\rho$ of the error terms of the two probits indicates whether the initial low-wage status is exogenous. Only if the error terms are not correlated $(\rho=0)$ does the simple probit model in (2) yield unbiased estimates of the determinants of upward mobility. Hence, we estimate the more general model (3) and take into account both the determinants of moving up as well as the factors determining the initial status of being a low-wage earner.

Table 4 presents regression results for the two years 2000 and 2003 and for two samples: for all full-time low-wage workers from 1998/99 (including those who were not employed full-time anymore in later years) and for the group of those individuals who continued to be full-time employed. Following the research questions and hypotheses in Sect. 3, explanatory variables in the upward mobility equation are individual characteristics (sex, age, level of education, foreigner), type of occupation, plant size, workforce composition (shares of women, low-wage earners, foreign workers, highly-qualified workers and age groups), location in eastern Germany and industry affiliation. In addition, the selection equation, which tries to take into account that the initial status of being a low-wage earner in 1998/99 and the selection into the sub-sample of workers still employed full-time may not be random, contains four identifying variables (regional unemployment rate in 1997, low-wage employment in 1997, work experience in 1993-1997 and part-time or 
Table 4 Advancement of multi-year low-wage workers in 2000 and 2003; probit estimations with sample selection; marginal effects

\begin{tabular}{|c|c|c|c|c|}
\hline \multirow[t]{2}{*}{ Independent variables } & \multicolumn{2}{|l|}{ All workers } & \multicolumn{2}{|c|}{ Still full-time employed workers } \\
\hline & 2000 & 2003 & 2000 & 2003 \\
\hline \multicolumn{5}{|l|}{ Upward mobility equation } \\
\hline Female $(1=$ yes $)$ & $\begin{array}{l}-0.053^{* * *} \\
(0.006)\end{array}$ & $\begin{array}{l}-0.111^{* * *} \\
(0.009)\end{array}$ & $\begin{array}{l}-0.059^{* * *} \\
(0.007)\end{array}$ & $\begin{array}{l}-0.123^{* * *} \\
(0.013)\end{array}$ \\
\hline Age $15-24(1=$ yes $)$ & $\begin{array}{l}0.062^{* * *} \\
(0.007)\end{array}$ & $\begin{array}{l}0.140^{* * *} \\
(0.009)\end{array}$ & $\begin{array}{l}0.055^{* * *} \\
(0.008)\end{array}$ & $\begin{array}{l}0.209^{* * *} \\
(0.014)\end{array}$ \\
\hline Age $25-34(1=$ yes $)$ & $\begin{array}{l}0.035^{* * *} \\
(0.005)\end{array}$ & $\begin{array}{l}0.060^{* * *} \\
(0.006)\end{array}$ & $\begin{array}{l}0.034^{* * *} \\
(0.005)\end{array}$ & $\begin{array}{l}0.098^{* * *} \\
(0.010)\end{array}$ \\
\hline Age $50-57(1=$ yes $)$ & $\begin{array}{l}-0.014^{* * *} \\
(0.005)\end{array}$ & $\begin{array}{l}-0.065^{* * *} \\
(0.006)\end{array}$ & $\begin{array}{l}-0.011^{*} \\
(0.006)\end{array}$ & $\begin{array}{l}-0.062^{* * *} \\
(0.011)\end{array}$ \\
\hline $\begin{array}{l}\text { School leaving certificate without } \\
\text { vocational training }(1=\text { yes })\end{array}$ & $\begin{array}{l}-0.015^{* * *} \\
(0.004)\end{array}$ & $\begin{array}{l}-0.028^{* * *} \\
(0.006)\end{array}$ & $\begin{array}{l}-0.016^{* * *} \\
(0.005)\end{array}$ & $\begin{array}{l}-0.040^{* * *} \\
(0.010)\end{array}$ \\
\hline $\begin{array}{l}\text { High school certificate with } \\
\text { vocational training }(1=\text { yes })\end{array}$ & $\begin{array}{l}0.038^{* *} \\
(0.017)\end{array}$ & $\begin{array}{l}0.033 \\
(0.021)\end{array}$ & $\begin{array}{l}0.050^{* *} \\
(0.020)\end{array}$ & $\begin{array}{l}0.063^{*} \\
(0.033)\end{array}$ \\
\hline University degree (1 = yes) & $\begin{array}{l}0.014 \\
(0.021)\end{array}$ & $\begin{array}{l}0.023 \\
(0.028)\end{array}$ & $\begin{array}{l}0.021 \\
(0.025)\end{array}$ & $\begin{array}{l}0.019 \\
(0.042)\end{array}$ \\
\hline Education unknown $(1=$ yes $)$ & $\begin{array}{l}0.002 \\
(0.005)\end{array}$ & $\begin{array}{l}-0.009 \\
(0.007)\end{array}$ & $\begin{array}{l}0.003 \\
(0.006)\end{array}$ & $\begin{array}{l}-0.017 \\
(0.011)\end{array}$ \\
\hline Foreigner $(1=$ yes $)$ & $\begin{array}{l}0.011 \\
(0.007)\end{array}$ & $\begin{array}{l}-0.021^{* *} \\
(0.008)\end{array}$ & $\begin{array}{l}0.016^{*} \\
(0.008)\end{array}$ & $\begin{array}{l}0.004 \\
(0.016)\end{array}$ \\
\hline Unskilled manual occupations ( $1=$ yes $)$ & $\begin{array}{l}-0.014^{* *} \\
(0.006)\end{array}$ & $\begin{array}{l}-0.033^{* * *} \\
(0.008)\end{array}$ & $\begin{array}{l}-0.025^{* * *} \\
(0.006)\end{array}$ & $\begin{array}{l}-0.056^{* * *} \\
(0.013)\end{array}$ \\
\hline Skilled manual occupations $(1=$ yes $)$ & $\begin{array}{l}-0.016^{* * *} \\
(0.005)\end{array}$ & $\begin{array}{l}-0.030^{* * *} \\
(0.008)\end{array}$ & $\begin{array}{l}-0.026^{* * *} \\
(0.006)\end{array}$ & $\begin{array}{l}-0.061^{* * *} \\
(0.012)\end{array}$ \\
\hline Unskilled services $(1=$ yes $)$ & $\begin{array}{l}-0.024^{* * *} \\
(0.005)\end{array}$ & $\begin{array}{l}-0.046^{* * *} \\
(0.007)\end{array}$ & $\begin{array}{l}-0.035^{* * *} \\
(0.005)\end{array}$ & $\begin{array}{l}-0.082^{* * *} \\
(0.011)\end{array}$ \\
\hline Skilled services $(1=$ yes $)$ & $\begin{array}{l}-0.024^{* * *} \\
(0.007)\end{array}$ & $\begin{array}{l}-0.031^{* * *} \\
(0.010)\end{array}$ & $\begin{array}{l}-0.031^{* * *} \\
(0.008)\end{array}$ & $\begin{array}{l}-0.050^{* * *} \\
(0.017)\end{array}$ \\
\hline $\begin{array}{l}\text { Unskilled commercial and administrative } \\
\text { occupations }(1=\text { yes })\end{array}$ & $\begin{array}{l}-0.018^{* * *} \\
(0.005)\end{array}$ & $\begin{array}{l}-0.047^{* * *} \\
(0.007)\end{array}$ & $\begin{array}{l}-0.028^{* * *} \\
(0.005)\end{array}$ & $\begin{array}{l}-0.074^{* * *} \\
(0.011)\end{array}$ \\
\hline Semi-professions $(1=$ yes $)$ & $\begin{array}{l}-0.004 \\
(0.012)\end{array}$ & $\begin{array}{l}-0.033^{* *} \\
(0.014)\end{array}$ & $\begin{array}{l}-0.003 \\
(0.013)\end{array}$ & $\begin{array}{l}-0.040 \\
(0.024)\end{array}$ \\
\hline Occupation type unknown $(1=$ yes $)$ & $\begin{array}{l}0.013 \\
(0.025)\end{array}$ & $\begin{array}{l}-0.017 \\
(0.030)\end{array}$ & $\begin{array}{l}-0.022 \\
(0.019)\end{array}$ & $\begin{array}{l}-0.029 \\
(0.048)\end{array}$ \\
\hline 21-100 employees $(1=$ yes $)$ & $\begin{array}{l}0.013^{* * *} \\
(0.004)\end{array}$ & $\begin{array}{l}0.010^{*} \\
(0.006)\end{array}$ & $\begin{array}{l}0.011^{* *} \\
(0.005)\end{array}$ & $\begin{array}{l}0.014 \\
(0.009)\end{array}$ \\
\hline $101-500$ employees $(1=$ yes $)$ & $\begin{array}{l}0.021^{* * *} \\
(0.006)\end{array}$ & $\begin{array}{l}0.023^{* * *} \\
(0.008)\end{array}$ & $\begin{array}{l}0.022^{* * *} \\
(0.007)\end{array}$ & $\begin{array}{l}0.049^{* * *} \\
(0.013)\end{array}$ \\
\hline More than 500 employees $(1=$ yes $)$ & $\begin{array}{l}0.013 \\
(0.010)\end{array}$ & $\begin{array}{l}0.031^{* *} \\
(0.014)\end{array}$ & $\begin{array}{l}0.033^{* *} \\
(0.014)\end{array}$ & $\begin{array}{l}0.086^{* * *} \\
(0.025)\end{array}$ \\
\hline Percentage of women & $\begin{array}{l}-1.50 \mathrm{E}-04^{* *} \\
(-7.31 \mathrm{E}-05)\end{array}$ & $\begin{array}{l}-7.59 \mathrm{E}-05 \\
(1.05 \mathrm{E}-04)\end{array}$ & $\begin{array}{l}3.09 \mathrm{E}-05 \\
(8.66 \mathrm{E}-05)\end{array}$ & $\begin{array}{l}-1.60 \mathrm{E}-04 \\
(1.74 \mathrm{E}-04)\end{array}$ \\
\hline Percentage of highly-qualified workers & $\begin{array}{l}-9.54 \mathrm{E}-05 \\
(1.30 \mathrm{E}-04)\end{array}$ & $\begin{array}{l}-7.03 \mathrm{E}-05 \\
(1.84 \mathrm{E}-04)\end{array}$ & $\begin{array}{l}-6.02 \mathrm{E}-05 \\
(1.50 \mathrm{E}-04)\end{array}$ & $\begin{array}{l}1.43 \mathrm{E}-04 \\
(3.08 \mathrm{E}-04)\end{array}$ \\
\hline Percentage of workers aged $15-24$ & $\begin{array}{l}3.21 \mathrm{E}-04^{* * *} \\
(1.12 \mathrm{E}-04)\end{array}$ & $\begin{array}{l}2.90 \mathrm{E}-04^{*} \\
(1.56 \mathrm{E}-04)\end{array}$ & $\begin{array}{l}2.99 \mathrm{E}-04^{* *} \\
(1.33 \mathrm{E}-04)\end{array}$ & $\begin{array}{l}1.85 \mathrm{E}-04 \\
(2.55 \mathrm{E}-04)\end{array}$ \\
\hline Percentage of workers aged 25-34 & $\begin{array}{l}1.61 \mathrm{E}-04 \\
(1.07 \mathrm{E}-04)\end{array}$ & $\begin{array}{l}1.14 \mathrm{E}-04 \\
(1.47 \mathrm{E}-04)\end{array}$ & $\begin{array}{l}2.25 \mathrm{E}-04^{*} \\
(1.24 \mathrm{E}-04)\end{array}$ & $\begin{array}{l}6.44 \mathrm{E}-06 \\
(2.35 \mathrm{E}-04)\end{array}$ \\
\hline Percentage of workers older than 49 & $\begin{array}{l}-1.21 \mathrm{E}-04 \\
(1.26 \mathrm{E}-04)\end{array}$ & $\begin{array}{l}-6.63 \mathrm{E}-05 \\
(1.69 \mathrm{E}-04)\end{array}$ & $\begin{array}{l}-5.49 \mathrm{E}-07 \\
(1.46 \mathrm{E}-04)\end{array}$ & $\begin{array}{l}-1.42 \mathrm{E}-04 \\
(2.70 \mathrm{E}-04)\end{array}$ \\
\hline
\end{tabular}


Table 4 Continued

\begin{tabular}{|c|c|c|c|c|}
\hline \multirow[t]{2}{*}{ Independent variables } & \multicolumn{2}{|l|}{ All workers } & \multicolumn{2}{|c|}{ Still full-time employed workers } \\
\hline & 2000 & 2003 & 2000 & 2003 \\
\hline Percentage of low-wage workers & $\begin{array}{l}-3.25 \mathrm{E}-04^{* * *} \\
(9.07 \mathrm{E}-05)\end{array}$ & $\begin{array}{l}-6.53 \mathrm{E}-04^{* * *} \\
(1.18 \mathrm{E}-04)\end{array}$ & $\begin{array}{l}-5.94 \mathrm{E}-04^{* * *} \\
(9.30 \mathrm{E}-05)\end{array}$ & $\begin{array}{l}-1.23 \mathrm{E}-03^{* * *} \\
(1.86 \mathrm{E} 04)\end{array}$ \\
\hline Percentage of foreign workers & $\begin{array}{l}-7.97 \mathrm{E}-05 \\
1.11 \mathrm{E}-04\end{array}$ & $\begin{array}{l}2.63 \mathrm{E}-04^{*} \\
(1.57 \mathrm{E}-04)\end{array}$ & $\begin{array}{l}-6.22 \mathrm{E}-05 \\
(1.34 \mathrm{E}-04)\end{array}$ & $\begin{array}{l}5.06 \mathrm{E}-04^{*} \\
(2.59 \mathrm{E}-04)\end{array}$ \\
\hline Plant located in eastern Germany $(1=$ yes $)$ & $\begin{array}{l}-0.006 \\
(0.004)\end{array}$ & $\begin{array}{l}-0.006 \\
(0.006)\end{array}$ & $\begin{array}{l}0.001 \\
(0.005)\end{array}$ & $\begin{array}{l}-0.014 \\
(0.009)\end{array}$ \\
\hline Change of plants $(1=$ yes $)$ & - & - & $\begin{array}{l}0.134^{* * *} \\
(0.005)\end{array}$ & $\begin{array}{l}0.188^{* * *} \\
(0.008)\end{array}$ \\
\hline Change of occupation type ( $1=$ yes $)$ & - & - & $\begin{array}{l}0.050^{* * *} \\
(0.009)\end{array}$ & $\begin{array}{l}0.093^{* * *} \\
(0.011)\end{array}$ \\
\hline Number of observations & 26,589 & 26,589 & 21,858 & 16,181 \\
\hline \multicolumn{5}{|l|}{ Selection equation } \\
\hline Regional unemployment rate in June 1997 & $\begin{array}{l}0.003^{* * *} \\
(0.001)\end{array}$ & $\begin{array}{l}0.003^{* * *} \\
(0.001)\end{array}$ & $\begin{array}{l}0.001 \\
(0.001)\end{array}$ & $\begin{array}{l}0.001 \\
(0.001)\end{array}$ \\
\hline Low-wage employment in 1997 ( $1=$ yes $)$ & $\begin{array}{l}0.576^{* * *} \\
(0.004)\end{array}$ & $\begin{array}{l}0.578^{* * *} \\
(0.004)\end{array}$ & $\begin{array}{l}0.553^{* * *} \\
(0.004)\end{array}$ & $\begin{array}{l}0.434^{* * *} \\
(0.004)\end{array}$ \\
\hline Years of work experience between 1993-1997 & $\begin{array}{l}-0.083^{* * *} \\
(0.001)\end{array}$ & $\begin{array}{l}-0.084^{* * *} \\
(0.001)\end{array}$ & $\begin{array}{l}-0.075^{* * *} \\
(0.002)\end{array}$ & $\begin{array}{l}-0.062^{* * *} \\
(0.002)\end{array}$ \\
\hline Part-time/marginal employed in 1997 (1 = yes) & $\begin{array}{l}0.185^{* * *} \\
(0.004)\end{array}$ & $\begin{array}{l}0.188^{* * *} \\
(0.004)\end{array}$ & $\begin{array}{l}0.276^{* * *} \\
(0.006)\end{array}$ & $\begin{array}{l}0.309^{* * *} \\
(0.010)\end{array}$ \\
\hline Number of observations & 237,278 & 237,278 & 237,278 & 237,278 \\
\hline$\rho$ (correlation of the error terms) & $0.159^{* * *}$ & $0.0731^{* * *}$ & $0.187^{* * *}$ & $0.163^{* * *}$ \\
\hline Significance of model & $\begin{array}{l}\chi 2(42)= \\
663.2^{* * *}\end{array}$ & $\begin{array}{l}\chi 2(42)= \\
1232.8^{* * *}\end{array}$ & $\begin{array}{l}\chi 2(44)= \\
1726.1^{* * *}\end{array}$ & $\begin{array}{l}\chi 2(44)= \\
1954.1^{* * *}\end{array}$ \\
\hline Joint significance of variable groups & $\begin{array}{l}\text { Age } \\
\text { of education }{ }^{* * *}, \\
\text { type of occupa- } \\
\text { tion***, firm } \\
\text { size } \\
\text { composition of } \\
\text { workers in the } \\
\text { firm }{ }^{* * *}, \text { industry } \\
\text { **** }\end{array}$ & $\begin{array}{l}\text { Age }^{* * *}, \text { level } \\
\text { of education } \\
\text { type of occupa- } \\
\text { tion } \\
\text { size }^{* * *}, \text { firm } \\
\text { composition of } \\
\text { workers in the } \\
\text { firm n.s., industry*** }\end{array}$ & $\begin{array}{l}\text { Age }{ }^{* * *}, \text { level } \\
\text { of education } \\
\text { type of occupa- } \\
\text { tion }{ }^{* * *}, \text { firm } \\
\text { size }^{* * *}, \text { age } \\
\text { composition of } \\
\text { workers in the } \\
\text { firm } \\
* *, \text { industry }\end{array}$ & $\begin{array}{l}\text { Age } e^{* * *}, \text { level } \\
\text { of education } \\
\text { type of occupa- } \\
\text { tion } \\
\text { size**, firm } \\
\text { composition of } \\
\text { workers in the } \\
\text { firm n.s., industry }\end{array}$ \\
\hline
\end{tabular}

Notes: own calculations based on BAP. Marginal effects calculated at the sample mean. Heteroscedasticity-consistent standard errors in parentheses (clustered at plant level). 16 industry dummies suppressed in the table. Reference categories of dummy variable groups: age 35-49, secondary school certificate with vocational training, skilled commercial and administrative occupations, 1-20 employees, percentage of workers aged 35-49. Significance levels: ${ }^{*} p<0.1{ }^{* *} p<0.05 ;{ }^{* *} p<0.01$; n.s. denotes statistical insignificance. The selection equation contains all variables from the upward mobility equation, except change of plant and change of occupation type.

marginal employment in 1997). ${ }^{8}$ Summary statistics of these variables are provided in an appendix table (Table 7).

\footnotetext{
${ }^{8}$ We thus assume that the recent individual labour market history and the unemployment rate in 1997 affect the probability of being low-paid in 1998 and 1999 but due to the temporal distance do not influence the probability of leaving low-wage employment in subsequent years. Of course we cannot rule out that the results might be sensitive to the exact specification of the selection equation, but other potential selection variables such as family background were not available in our data set.
}

In Table 4, the variables in the selection equation show the expected relationship with being in the low-wage earner category in 1998/99, and they are, in most cases, statistically significant. In all estimations the hypothesis that the error terms are uncorrelated $(\rho=0)$ is rejected, so that a simple probit model not taking account of endogenous selection would result in biased estimates. In the upward mobility equation, the results in the first two columns indicate that individual, as well as occupational and plant characteristics, 
seem to play a statistically significant role for individuals' probability of leaving the low-wage sector. However, when interpreting these results it should be kept in mind that in this probit analysis for all low-wage workers the 0 in the dependent variable includes those individuals for which we do not have information, those in marginal or part-time employment, and those leaving the labour market, which could reflect voluntary decisions of the low-wage earners observed. Therefore, relationships may be identified with a greater degree of certainty if they also show up in the estimations for the sub-sample of individuals that continue to be full-time employed reported in the last two columns of Table 4. The latter estimations also include dummy variables for moving to another plant or occupation, which is not possible in the estimations for all low-wage workers (some of whom are not employed anymore).

The estimates in Table 4 for the years 2000 and 2003 usually point in the same direction, with effects often being more pronounced in the longer term. Looking at individual characteristics first, all estimations indicate that women are substantially less likely to escape from low-paid work than men, even if they continue to be full-time employed. The results in the last column (which are marginal effects calculated according to Stewart and Swaffield 1999) imply that a woman's probability of achieving higher-paid work (conditional on the selection that she was a low-wage earner in $1998 / 99$ and continues to be full-time employed in 2003) is about 12 percentage points lower than that of a man with similar characteristics. Upward wage mobility is also lower for older and for unskilled employees, whereas there is no clear difference between German and foreign employees. Compared to the reference group of skilled commercial and administrative occupations, the chance of leaving the lowwage sector is lower in all other groups of occupations except semi-professions.

Turning to plant characteristics, we see that the size of the employing plant in 1999 significantly affects individuals' chances of upward wage mobility in the following years. Workers who continue to be full-time employed in a plant with more than 500 employees, for instance, have a chance of leaving low-paid work by 2003 that is almost 9 percentage points higher than that of similar workers employed in the reference group of plants with no more than 20 employees. Industry affiliation also plays a significant role for upward wage mobility, ${ }^{9}$ whereas the location of a plant in eastern Germany does not seem to be relevant (this will be different for men in Table 5).

\footnotetext{
${ }^{9}$ Compared to the reference group of "wholesale and retail trade; repair of motor vehicles, motorcycles and personal and household goods", the probability of obtaining a higher-paid job is significantly lower if the low-wage earner was initially employed in the sectors "manufacture of food products and beverages", "hotels and restaurants" and "other service activities".
}

The composition of a plant's workforce is of less importance for reaching higher-paid employment than expected. The coefficients of the percentages of foreigners and of qualified workers are never statistically significant at the five percent level, and by 2003 the percentage of women and the age composition have lost their initial significance. One notable exception is the percentage of low-wage workers in a plant which shows a highly significant negative relationship with upward wage mobility. The marginal effect shown in the last column of Table 4 implies that an increase in the share of low-paid workers by 10 percentage points is associated with a reduction in an individual's chance of obtaining higher-paid work of 1.2 percentage points.

Finally, the estimations in the last two columns suggest that moving to another plant and changing occupations both significantly increase the chance of leaving low-paid work. Taken at face value, by 2003 the (conditional) probability of upward wage mobility is almost 19 percentage points higher if the initial low-wage earner has moved to another plant (and about 9 percentage points higher if he or she has changed occupations). These results should not be taken too literally, however, because obtaining higher wages is usually the main aim of such (voluntary) moves, so that most of these may be endogenous.

Since the results in Table 4 indicate that upward wage mobility is significantly lower for women, which could reflect deeper gender-specific differences, Table 5 presents separate estimations for men and women for the year 2003. While occupational differences seem to be more pronounced for women and a plant's location in eastern Germany plays a (negative) role for men but not for women, by and large this robustness check confirms the insights described above. The split of sample according to gender also enables us to test the segregation hypothesis set up above. In contrast to this hypothesis, womens' chances of leaving the low-wage sector are not significantly lower when the percentage of women in a plant is higher.

In order to test this and the other hypotheses concerning dead ends more specifically and to see where changes of plants and occupations are most successful, we include some interaction effects in the estimations for (full-time employed) men and women in 2003 reported in Table 6. These show quite clearly that plants with high shares of women or of foreigners are not dead-end plants for women and foreigners since the respective interaction terms prove to be insignificant. ${ }^{10}$ In contrast, plants with a high share of low-wage earners seem to be dead ends since there, the chance of upward wage mobility is significantly lower for

\footnotetext{
${ }^{10}$ Since the interpretation of interaction effects in non-linear estimators is not straightforward (see $\mathrm{Ai}$ and Norton 2003), we repeated the estimations in Table 6 with a linear probability model, which did not change our insights.
} 
Table 5 Upward mobility of multi-year low-wage workers in 2003 by gender; probit estimations with sample selection; marginal effects

\begin{tabular}{|c|c|c|c|c|}
\hline \multirow[t]{2}{*}{ Independent variables } & \multicolumn{2}{|l|}{ All workers } & \multicolumn{2}{|c|}{ Still full-time employed workers } \\
\hline & Women & Men & Women & Men \\
\hline \multicolumn{5}{|l|}{ Upward mobility equation } \\
\hline Age $15-24(1=$ yes $)$ & $\begin{array}{l}0.126^{* * *} \\
(0.010)\end{array}$ & $\begin{array}{l}0.180^{* * *} \\
(0.021)\end{array}$ & $\begin{array}{l}0.202^{* * *} \\
(0.016)\end{array}$ & $\begin{array}{l}0.219^{* * *} \\
(0.029)\end{array}$ \\
\hline Age $25-34$ ( $1=$ yes $)$ & $\begin{array}{l}0.042^{* * *} \\
(0.007)\end{array}$ & $\begin{array}{l}0.112^{* * * *} \\
(0.014)\end{array}$ & $\begin{array}{l}0.085^{* * *} \\
(0.012)\end{array}$ & $\begin{array}{l}0.129^{* * *} \\
(0.020)\end{array}$ \\
\hline Age $50-57(1=$ yes $)$ & $\begin{array}{l}-0.059^{* * *} \\
(0.006)\end{array}$ & $\begin{array}{l}-0.075^{* * *} \\
(0.017)\end{array}$ & $\begin{array}{l}-0.054^{* * *} \\
(0.011)\end{array}$ & $\begin{array}{l}-0.072^{* *} \\
(0.029)\end{array}$ \\
\hline $\begin{array}{l}\text { School leaving certificate without } \\
\text { vocational training }(1=\text { yes })\end{array}$ & $\begin{array}{l}-0.025^{* * *} \\
(0.006)\end{array}$ & $\begin{array}{l}-0.030^{* *} \\
(0.013)\end{array}$ & $\begin{array}{l}-0.036^{* * *} \\
(0.011)\end{array}$ & $\begin{array}{l}-0.040^{*} \\
(0.021)\end{array}$ \\
\hline $\begin{array}{l}\text { High school certificate with } \\
\text { vocational training }(1=\text { yes })\end{array}$ & $\begin{array}{l}0.020 \\
(0.020)\end{array}$ & $\begin{array}{l}0.100 \\
(0.063)\end{array}$ & $\begin{array}{l}0.041 \\
(0.033)\end{array}$ & $\begin{array}{l}0.154^{*} \\
(0.079)\end{array}$ \\
\hline University degree $(1=$ yes $)$ & $\begin{array}{l}0.026 \\
(0.030)\end{array}$ & $\begin{array}{l}0.013 \\
(0.067)\end{array}$ & $\begin{array}{l}0.032 \\
(0.045)\end{array}$ & $\begin{array}{l}-0.001 \\
(0.094)\end{array}$ \\
\hline Education unknown (1 = yes) & $\begin{array}{l}-0.009 \\
(0.007)\end{array}$ & $\begin{array}{l}-0.007 \\
(0.015)\end{array}$ & $\begin{array}{l}-0.018 \\
(0.012)\end{array}$ & $\begin{array}{l}-0.008 \\
(0.024)\end{array}$ \\
\hline Foreigner $(1=$ yes $)$ & $\begin{array}{l}-0.020^{* *} \\
(0.010)\end{array}$ & $\begin{array}{l}-0.025 \\
(0.018)\end{array}$ & $\begin{array}{l}-0.003 \\
(0.019)\end{array}$ & $\begin{array}{l}0.014 \\
(0.029)\end{array}$ \\
\hline Unskilled manual occupations ( $1=$ yes $)$ & $\begin{array}{l}-0.026^{* * *} \\
(0.008)\end{array}$ & $\begin{array}{l}-0.039 \\
(0.025)\end{array}$ & $\begin{array}{l}-0.038^{* * *} \\
(0.014)\end{array}$ & $\begin{array}{l}-0.081^{* *} \\
(0.038)\end{array}$ \\
\hline Skilled manual occupations ( $1=$ yes $)$ & $\begin{array}{l}-0.049^{* * *} \\
(0.008)\end{array}$ & $\begin{array}{l}-0.014 \\
(0.024)\end{array}$ & $\begin{array}{l}-0.086^{* * *} \\
(0.013)\end{array}$ & $\begin{array}{l}-0.047 \\
(0.037)\end{array}$ \\
\hline Unskilled services $(1=$ yes $)$ & $\begin{array}{l}-0.045^{* * *} \\
(0.007)\end{array}$ & $\begin{array}{l}-0.051^{* *} \\
(0.024)\end{array}$ & $\begin{array}{l}-0.077^{* * *} \\
(0.011)\end{array}$ & $\begin{array}{l}-0.095^{* * *} \\
(0.036)\end{array}$ \\
\hline Skilled services $(1=$ yes $)$ & $\begin{array}{l}-0.032^{* * *} \\
(0.010)\end{array}$ & $\begin{array}{l}-0.071^{*} \\
(0.038)\end{array}$ & $\begin{array}{l}-0.052^{* * *} \\
(0.016)\end{array}$ & $\begin{array}{l}-0.056 \\
(0.068)\end{array}$ \\
\hline $\begin{array}{l}\text { Unskilled commercial and administrative } \\
\text { occupations }(1=\text { yes })\end{array}$ & $\begin{array}{l}-0.039^{* * *} \\
(0.007)\end{array}$ & $\begin{array}{l}-0.066^{* *} \\
(0.026)\end{array}$ & $\begin{array}{l}-0.059^{* * *} \\
(0.011)\end{array}$ & $\begin{array}{l}-0.091^{* *} \\
(0.044)\end{array}$ \\
\hline Semi-professions $(1=$ yes $)$ & $\begin{array}{l}-0.037^{* * *} \\
(0.012)\end{array}$ & $\begin{array}{l}0.031 \\
(0.062)\end{array}$ & $\begin{array}{l}-0.048^{* *} \\
(0.021)\end{array}$ & $\begin{array}{l}0.037 \\
(0.098)\end{array}$ \\
\hline Occupation type unknown ( $1=$ yes $)$ & $\begin{array}{l}-0.034 \\
(0.030)\end{array}$ & $\begin{array}{l}0.037 \\
(0.077)\end{array}$ & $\begin{array}{l}-0.057 \\
(0.047)\end{array}$ & $\begin{array}{l}0.050 \\
(0.118)\end{array}$ \\
\hline 21-100 employees $(1=$ yes $)$ & $\begin{array}{l}0.006 \\
(0.006)\end{array}$ & $\begin{array}{l}0.031^{* *} \\
(0.014)\end{array}$ & $\begin{array}{l}0.004 \\
(0.010)\end{array}$ & $\begin{array}{l}0.049^{* *} \\
(0.021)\end{array}$ \\
\hline 101-500 employees $(1=$ yes $)$ & $\begin{array}{l}0.021^{* *} \\
(0.008)\end{array}$ & $\begin{array}{l}0.036^{* *} \\
(0.018)\end{array}$ & $\begin{array}{l}0.047^{* * *} \\
(0.014)\end{array}$ & $\begin{array}{l}0.054^{* *} \\
(0.027)\end{array}$ \\
\hline More than 500 employees $(1=$ yes $)$ & $\begin{array}{l}0.022 \\
(0.015)\end{array}$ & $\begin{array}{l}0.076^{* *} \\
(0.035)\end{array}$ & $\begin{array}{l}0.076^{* * *} \\
(0.028)\end{array}$ & $\begin{array}{l}0.115^{* *} \\
(0.052)\end{array}$ \\
\hline Percentage of women & $\begin{array}{c}-1.03 \mathrm{E}-04 \\
(1.26 \mathrm{E}-04)\end{array}$ & $\begin{array}{c}-1.17 \mathrm{E}-04 \\
(2.44 \mathrm{E}-04)\end{array}$ & $\begin{array}{l}-1.06 \mathrm{E}-04 \\
(2.14 \mathrm{E}-04)\end{array}$ & $\begin{array}{l}-1.57 \mathrm{E}-04 \\
(3.73 \mathrm{E}-04)\end{array}$ \\
\hline Percentage of highly-qualified workers & $\begin{array}{l}7.52 \mathrm{E}-05 \\
(1.92 \mathrm{E}-04)\end{array}$ & $\begin{array}{l}-4.84 \mathrm{E}-04 \\
(4.65 \mathrm{E}-04)\end{array}$ & $\begin{array}{l}1.79 \mathrm{E}-04 \\
(3.18 \mathrm{E}-04)\end{array}$ & $\begin{array}{l}-7.52 \mathrm{E}-05 \\
(7.49 \mathrm{E}-04)\end{array}$ \\
\hline Percentage of workers aged 15-24 & $\begin{array}{l}2.16 \mathrm{E}-04 \\
(1.65 \mathrm{E}-04)\end{array}$ & $\begin{array}{l}3.43 \mathrm{E}-04 \\
(3.82 \mathrm{E} 04)\end{array}$ & $\begin{array}{l}1.53 \mathrm{E}-04 \\
(2.70 \mathrm{E}-04)\end{array}$ & $\begin{array}{l}1.06 \mathrm{E}-04 \\
(5.89 \mathrm{E}-04)\end{array}$ \\
\hline Percentage of workers aged $25-34$ & $\begin{array}{l}2.50 \mathrm{E}-04 \\
(1.58 \mathrm{E}-04)\end{array}$ & $\begin{array}{l}-3.11 \mathrm{E}-04 \\
(3.41 \mathrm{E}-04)\end{array}$ & $\begin{array}{l}1.96 \mathrm{E}-04 \\
(2.53 \mathrm{E}-04)\end{array}$ & $\begin{array}{c}-6.66 \mathrm{E}-04 \\
(5.15 \mathrm{E}-04)\end{array}$ \\
\hline
\end{tabular}


Table 5 Continued

\begin{tabular}{|c|c|c|c|c|}
\hline \multirow[t]{2}{*}{ Independent variables } & \multicolumn{2}{|l|}{ All workers } & \multicolumn{2}{|c|}{ Still full-time employed workers } \\
\hline & Women & Men & Women & Men \\
\hline Percentage of workers older than 49 & $\begin{array}{l}-9.50 \mathrm{E}-05 \\
(1.80 \mathrm{E}-04)\end{array}$ & $\begin{array}{l}-3.32 \mathrm{E}-05 \\
(4.08 \mathrm{E}-04)\end{array}$ & $\begin{array}{l}-2.44 \mathrm{E}-04 \\
(2.89 \mathrm{E}-04)\end{array}$ & $\begin{array}{l}1.49 \mathrm{E}-04 \\
(6.14 \mathrm{E} 04)\end{array}$ \\
\hline Percentage of low-wage workers & $\begin{array}{l}-6,34 \mathrm{E}-04^{* * *} \\
(1.24 \mathrm{E}-04)\end{array}$ & $\begin{array}{l}-5.78 \mathrm{E}-04^{*} \\
(3.19 \mathrm{E}-04)\end{array}$ & $\begin{array}{l}-1.32 \mathrm{E}-03^{* * *} \\
(2.00 \mathrm{E}-04)\end{array}$ & $\begin{array}{l}-9.35 \mathrm{E}-04^{* *} \\
(4.57 \mathrm{E}-04)\end{array}$ \\
\hline Percentage of foreign workers & $\begin{array}{l}4.65 \mathrm{E}-04^{* *} \\
(1.92 \mathrm{E}-04)\end{array}$ & $\begin{array}{l}1.06 \mathrm{E}-05 \\
(3.10 \mathrm{E}-04)\end{array}$ & $\begin{array}{l}\text { 7.43E-04** } \\
(3.18 \mathrm{E}-04)\end{array}$ & $\begin{array}{l}1.74 \mathrm{E}-04 \\
(4.83 \mathrm{E}-04)\end{array}$ \\
\hline Plant located in eastern Germany $(1=$ yes $)$ & $\begin{array}{l}0.007 \\
(0.006)\end{array}$ & $\begin{array}{l}-0.037^{* * *} \\
(0.012)\end{array}$ & $\begin{array}{l}0.003 \\
(0.010)\end{array}$ & $\begin{array}{l}-0.056^{* * *} \\
(0.019)\end{array}$ \\
\hline Change of plants $(1=$ yes $)$ & - & - & $\begin{array}{l}0.146^{* * *} \\
(0.008)\end{array}$ & $\begin{array}{l}0.300^{* * *} \\
(0.018)\end{array}$ \\
\hline Change of occupation type $(1=$ yes $)$ & - & - & $\begin{array}{l}0.103^{* * *} \\
(0.014)\end{array}$ & $\begin{array}{l}0.080^{* * *} \\
(0.021)\end{array}$ \\
\hline Number of observations & 19,621 & 6,968 & 11,821 & 4,360 \\
\hline \multicolumn{5}{|l|}{ Selection equation } \\
\hline Regional unemployment rate in June 1997 & $\begin{array}{l}0.001 \\
(0.001)\end{array}$ & $\begin{array}{l}0.008^{* * *} \\
(0.001)\end{array}$ & $\begin{array}{l}-0.001 \\
(0.001)\end{array}$ & $\begin{array}{l}0.004^{* * *} \\
(0.001)\end{array}$ \\
\hline Low-wage employment in 1997 ( $1=$ yes $)$ & $\begin{array}{l}0.599^{* * *} \\
(0.005)\end{array}$ & $\begin{array}{l}0.523^{* * *} \\
(0.007)\end{array}$ & $\begin{array}{l}0.453^{* * *} \\
(0.005)\end{array}$ & $\begin{array}{l}0.381^{* * *} \\
(0.007)\end{array}$ \\
\hline Years of work experience between 1993-1997 & $\begin{array}{l}-0.076^{* * *} \\
(0.002)\end{array}$ & $\begin{array}{l}-0.098^{* * *} \\
(0.003)\end{array}$ & $\begin{array}{l}-0.064^{* * *} \\
(0.002)\end{array}$ & $\begin{array}{l}-0.054^{* * *} \\
(0.003)\end{array}$ \\
\hline Part-time/marginal employed in 1997 ( $1=$ yes $)$ & $\begin{array}{l}0.161^{* * *} \\
(0.003)\end{array}$ & $\begin{array}{l}0.219^{* * *} \\
(0.014)\end{array}$ & $\begin{array}{l}0.334^{* * *} \\
(0.010)\end{array}$ & $\begin{array}{l}0.243^{* * *} \\
(0.021)\end{array}$ \\
\hline Number of observations & 88,721 & 148,557 & 88,721 & 148,557 \\
\hline$\rho$ (correlation of the error terms) & 0.0312 & $0.138^{* * *}$ & $0.124^{* * *}$ & $0.217^{* * *}$ \\
\hline Significance of the model & $\begin{array}{l}\times 2(41)= \\
734.7^{* * *}\end{array}$ & $\begin{array}{l}\chi 2(41)= \\
320.9^{* * *}\end{array}$ & $\begin{array}{l}\chi 2(43)= \\
1212.6^{* * *}\end{array}$ & $\begin{array}{l}\times 2(41)= \\
659.4^{* * *}\end{array}$ \\
\hline Joint significance of variable groups & $\begin{array}{l}\text { Age }{ }^{* * *}, \text { level } \\
\text { of education***, } \\
\text { type of occupa- } \\
\text { tion***, plant } \\
\text { size* }^{* *} \text { age } \\
\text { composition of } \\
\text { workers in the } \\
\text { plant n.s., industry*** }\end{array}$ & $\begin{array}{l}\text { Age }{ }^{* * *}, \text { level } \\
\text { of education*, } \\
\text { type of occupa- } \\
\text { tion**, plant } \\
\text { size }^{* *}, \\
\text { composition of } \\
\text { workers in the } \\
\text { plant n.s., industry*** }\end{array}$ & $\begin{array}{l}\text { Age } e^{* * *}, \text { level } \\
\text { of education } \\
\text { type of occupa- } \\
\text { tion } \\
\text { size }^{* * *}, \text { plant } \\
\text { composition of } \\
\text { workers in the } \\
\text { plant n.s., industry*** }\end{array}$ & $\begin{array}{l}\text { Age }{ }^{* * *}, \text { level } \\
\text { of education*, } \\
\text { type of occupa- } \\
\text { tion*, plant } \\
\text { size }^{* *} \text {, age } \\
\text { composition of } \\
\text { workers in the } \\
\text { plant n.s., industry n.s. }\end{array}$ \\
\hline
\end{tabular}

Notes: own calculations based on BAP. Marginal effects calculated at the sample mean. Heteroscedasticity-consistent standard errors in parentheses (clustered at plant level). 16 industry dummies suppressed in the table. Reference categories of dummy variable groups: age 35-49, secondary school certificate with vocational training, skilled commercial and administrative occupations, 1-20 employees, percentage of workers aged 35-49. Significance levels: ${ }^{*} p<0.1{ }^{* *} p<0.05 ;{ }^{* * *} p<0.01$; n.s. denotes statistical insignificance. The selection equation contains all variables from the upward mobility equation, except change of plant and change of occupation type.

women and particularly for men. Moreover, the positive interaction term of the share of low-wage earners and the change of plants indicates that moving out of these dead-end plants is usually associated with leaving low-wage employment.
Small plants appear to be another dead end for low-wage earners. Upward wage mobility is relatively low when staying in plants with no more than 100 employees, whereas it is significantly higher in larger plants. Moreover, as the interaction effects indicate, in larger plants with more than 
Table 6 Upward mobility of multi-year low-wage workers in 2003 including interaction effects; probit estimations with sample selection; marginal effects

\begin{tabular}{|c|c|c|c|}
\hline \multirow[t]{2}{*}{ Independent variables } & \multicolumn{3}{|c|}{ Still full-time employed workers } \\
\hline & Women and men & Women & Men \\
\hline \multicolumn{4}{|l|}{ Upward mobility equation } \\
\hline Female $(1=$ yes $)$ & $\begin{array}{l}-0.129^{* * *} \\
(0.023)\end{array}$ & - & - \\
\hline Age $15-24$ (1= yes) & $\begin{array}{l}0.213^{* * *} \\
(0.014)\end{array}$ & $\begin{array}{l}0.203^{* * *} \\
(0.016)\end{array}$ & $\begin{array}{l}0.231^{* * *} \\
(0.029)\end{array}$ \\
\hline Age $25-34(1=$ yes $)$ & $\begin{array}{l}0.098^{* * *} \\
(0.010)\end{array}$ & $\begin{array}{l}0.086^{* * *} \\
(0.012)\end{array}$ & $\begin{array}{l}0.130^{* * *} \\
(0.020)\end{array}$ \\
\hline Age $50-57$ (1=yes) & $\begin{array}{l}-0.063^{* * *} \\
(0.011)\end{array}$ & $\begin{array}{l}-0.055^{* * *} \\
(0.011)\end{array}$ & $\begin{array}{l}-0.073^{* *} \\
(0.029)\end{array}$ \\
\hline $\begin{array}{l}\text { School leaving certificate without } \\
\text { vocational training }(1=\text { yes })\end{array}$ & $\begin{array}{l}-0.041^{* * *} \\
(0.010)\end{array}$ & $\begin{array}{l}-0.037^{* * *} \\
(0.011)\end{array}$ & $\begin{array}{l}-0.043^{* *} \\
(0.021)\end{array}$ \\
\hline $\begin{array}{l}\text { High school certificate with } \\
\text { vocational training }(1=\text { yes })\end{array}$ & $\begin{array}{l}0.061^{*} \\
(0.033)\end{array}$ & $\begin{array}{l}0.043 \\
(0.033)\end{array}$ & $\begin{array}{l}0.162^{* *} \\
(0.082)\end{array}$ \\
\hline University degree $(1=$ yes $)$ & $\begin{array}{l}0.026 \\
(0.042)\end{array}$ & $\begin{array}{l}0.046 \\
(0.046)\end{array}$ & $\begin{array}{l}-0.018 \\
(0.095)\end{array}$ \\
\hline Education unknown ( $1=$ yes $)$ & $\begin{array}{l}-0.017 \\
(0.011)\end{array}$ & $\begin{array}{l}-0.018 \\
(0.012)\end{array}$ & $\begin{array}{l}-0.008 \\
(0.024)\end{array}$ \\
\hline Foreigner $(1=$ yes $)$ & $\begin{array}{l}0.020 \\
(0.021)\end{array}$ & $\begin{array}{l}0.018 \\
(0.026)\end{array}$ & $\begin{array}{l}0.019 \\
(0.039)\end{array}$ \\
\hline Unskilled manual occupations $(1=$ yes $)$ & $\begin{array}{l}-0.051^{* * *} \\
(0.014)\end{array}$ & $\begin{array}{l}-0.040^{* * *} \\
(0.014)\end{array}$ & $\begin{array}{l}-0.075^{*} \\
(0.042)\end{array}$ \\
\hline Skilled manual occupations $(1=$ yes $)$ & $\begin{array}{l}-0.066^{* * *} \\
(0.013)\end{array}$ & $\begin{array}{l}-0.078^{* * *} \\
(0.015)\end{array}$ & $\begin{array}{l}-0.074^{*} \\
(0.040)\end{array}$ \\
\hline Unskilled services $(1=$ yes $)$ & $\begin{array}{l}-0.097^{* * *} \\
(0.012)\end{array}$ & $\begin{array}{l}-0.089^{* * *} \\
(0.012)\end{array}$ & $\begin{array}{l}-0.129^{* * *} \\
(0.040)\end{array}$ \\
\hline Skilled services $(1=$ yes $)$ & $\begin{array}{l}-0.072^{* * *} \\
(0.017)\end{array}$ & $\begin{array}{l}-0.071^{* * *} \\
(0.016)\end{array}$ & $\begin{array}{l}-0.120^{*} \\
(0.071)\end{array}$ \\
\hline $\begin{array}{l}\text { Unskilled commercial and administrative } \\
\text { occupations }(1=\text { yes })\end{array}$ & $\begin{array}{l}-0.089^{* * *} \\
(0.012)\end{array}$ & $\begin{array}{l}-0.072^{* * *} \\
(0.011)\end{array}$ & $\begin{array}{l}-0.133^{* * *} \\
(0.048)\end{array}$ \\
\hline Semi-professions $(1=$ yes $)$ & $\begin{array}{l}-0.038 \\
(0.026)\end{array}$ & $\begin{array}{l}-0.049^{* *} \\
(0.022)\end{array}$ & $\begin{array}{l}0.116 \\
(0.118)\end{array}$ \\
\hline $21-100$ employees $(1=$ yes $)$ & $\begin{array}{l}0.010 \\
(0.012)\end{array}$ & $\begin{array}{l}0.014 \\
(0.012)\end{array}$ & $\begin{array}{l}2.10 \mathrm{E}-04 \\
(0.030)\end{array}$ \\
\hline $101-500$ employees $(1=$ yes $)$ & $\begin{array}{l}0.043^{* * *} \\
(0.016)\end{array}$ & $\begin{array}{l}0.050^{* * *} \\
(0.017)\end{array}$ & $\begin{array}{l}0.021 \\
(0.037)\end{array}$ \\
\hline More than 500 employees $(1=$ yes $)$ & $\begin{array}{l}0.104^{* * *} \\
(0.030)\end{array}$ & $\begin{array}{l}0.095^{* * *} \\
(0.032)\end{array}$ & $\begin{array}{l}0.195^{* *} \\
(0.079)\end{array}$ \\
\hline Percentage of women & $\begin{array}{l}-6.49 \mathrm{E}-05 \\
(2.61 \mathrm{E}-04)\end{array}$ & $\begin{array}{l}-9.53 \mathrm{E}-05 \\
(2.13 \mathrm{E}-04)\end{array}$ & $\begin{array}{l}-5.10 \mathrm{E}-05 \\
(3.79 \mathrm{E}-04)\end{array}$ \\
\hline Percentage of highly-qualified workers & $\begin{array}{l}1.61 \mathrm{E}-04 \\
(3.04 \mathrm{E}-04)\end{array}$ & $\begin{array}{l}1.60 \mathrm{E}-04 \\
(3.15 \mathrm{E}-03)\end{array}$ & $\begin{array}{l}1.57 \mathrm{E}-04 \\
(7.55 \mathrm{E}-04)\end{array}$ \\
\hline Percentage of workers aged $15-24$ & $\begin{array}{l}1.47 \mathrm{E}-04 \\
(2.58 \mathrm{E}-04)\end{array}$ & $\begin{array}{l}1.42 \mathrm{E}-04 \\
(2.73 \mathrm{E}-04)\end{array}$ & $\begin{array}{l}5.19 \mathrm{E}-07 \\
6.00 \mathrm{E}-04\end{array}$ \\
\hline Percentage of workers aged $25-34$ & $\begin{array}{l}8.55 \mathrm{E}-07 \\
(2.37 \mathrm{E}-04)\end{array}$ & $\begin{array}{l}1.86 \mathrm{E}-04 \\
(2.55 \mathrm{E}-04)\end{array}$ & $\begin{array}{l}-5.40 \mathrm{E}-04 \\
5.27 \mathrm{E}-04\end{array}$ \\
\hline Percentage of workers older than 49 & $\begin{array}{l}-2.93 \mathrm{E}-05 \\
(2.73 \mathrm{E}-04)\end{array}$ & $\begin{array}{l}-1.85 \mathrm{E}-04 \\
(2.91 \mathrm{E}-04)\end{array}$ & $\begin{array}{l}5.00 \mathrm{E}-04 \\
(6.29 \mathrm{E}-04)\end{array}$ \\
\hline
\end{tabular}


Table 6 Continued

\begin{tabular}{|c|c|c|c|}
\hline \multirow[t]{2}{*}{ Independent variables } & \multicolumn{3}{|c|}{ Still full-time employed workers } \\
\hline & Women and men & Women & Men \\
\hline Percentage of low-wage workers & $\begin{array}{l}-1.93 \mathrm{E}-03^{* * *} \\
(2.21 \mathrm{E}-04)\end{array}$ & $\begin{array}{l}-1.59 \mathrm{E}-03^{* * *} \\
(2.28 \mathrm{E}-04)\end{array}$ & $\begin{array}{l}-2.97 \mathrm{E}-03^{* * *} \\
(5.51 \mathrm{E}-04)\end{array}$ \\
\hline Percentage of foreign workers & $\begin{array}{l}7.15 \mathrm{E}-04^{* *} \\
(3.48 \mathrm{E}-04)\end{array}$ & $\begin{array}{l}9.98 \mathrm{E}-04^{* *} \\
(3.96 \mathrm{E}-04)\end{array}$ & $\begin{array}{l}1.40 \mathrm{E}-04 \\
(7.07 \mathrm{E}-04)\end{array}$ \\
\hline $\begin{array}{l}\text { Plant located in eastern Germany } \\
(1=\text { yes })\end{array}$ & $\begin{array}{l}-0.011 \\
(0.009)\end{array}$ & $\begin{array}{l}0.006 \\
(0.010)\end{array}$ & $\begin{array}{l}-0.051^{* * *} \\
(0.020)\end{array}$ \\
\hline Female $\times$ percentage of women & $\begin{array}{l}-2,94 \mathrm{E}-05 \\
(3,32 \mathrm{E}-04)\end{array}$ & - & - \\
\hline Foreigner $\times$ percentage of foreigners & $\begin{array}{l}-0.001 \\
(0.001)\end{array}$ & $\begin{array}{l}-0.001 \\
(0.001)\end{array}$ & $\begin{array}{l}-2.44 \mathrm{E}-04 \\
(0.001)\end{array}$ \\
\hline Change of plant $(1=$ yes $)$ & $\begin{array}{l}0.082^{* * *} \\
(0.019)\end{array}$ & $\begin{array}{l}0.109^{* * *} \\
(0.021)\end{array}$ & $\begin{array}{l}-0.005 \\
(0.047)\end{array}$ \\
\hline $\begin{array}{l}21-100 \text { employees } \times \text { change of plant } \\
(1=\text { yes })\end{array}$ & $\begin{array}{l}0.002 \\
(0.017)\end{array}$ & $\begin{array}{l}-0.028 \\
(0.018)\end{array}$ & $\begin{array}{l}0.073^{*} \\
(0.039)\end{array}$ \\
\hline $\begin{array}{l}101-500 \text { employees } \times \text { change of plant } \\
(1=\text { yes })\end{array}$ & $\begin{array}{l}-0.002 \\
(0.021)\end{array}$ & $\begin{array}{l}-0.013 \\
(0.024)\end{array}$ & $\begin{array}{l}0.045 \\
(0.046)\end{array}$ \\
\hline $\begin{array}{l}\text { More than } 500 \text { employees } \times \text { change } \\
\text { of plant }(1=\text { yes })\end{array}$ & $\begin{array}{l}-0.081^{* *} \\
(0.038)\end{array}$ & $\begin{array}{l}-0.079^{*} \\
(0.047)\end{array}$ & $\begin{array}{l}-0.145 \\
(0.091)\end{array}$ \\
\hline $\begin{array}{l}\text { Percentage of low-paid workers } \times \\
\text { change of plant }(1=\text { yes })\end{array}$ & $\begin{array}{l}0.002^{* * *} \\
(2.37 \mathrm{E}-04)\end{array}$ & $\begin{array}{l}0.001^{* * *} \\
(2.58 \mathrm{E}-04)\end{array}$ & $\begin{array}{l}0.004^{* * *} \\
(5.5 \mathrm{E}-04)\end{array}$ \\
\hline Change of occupation type (1 = yes) & $\begin{array}{l}0.015 \\
(0.025)\end{array}$ & $\begin{array}{l}0.020 \\
(0.025)\end{array}$ & $\begin{array}{l}-0.014 \\
(0.076)\end{array}$ \\
\hline $\begin{array}{l}\text { Unskilled manual occupation } \times \\
\text { change of occupation type }(1=\text { yes })\end{array}$ & $\begin{array}{l}-0.003 \\
(0.031)\end{array}$ & $\begin{array}{l}0.024 \\
(0.037)\end{array}$ & $\begin{array}{l}0.003 \\
(0.084)\end{array}$ \\
\hline $\begin{array}{l}\text { Skilled manual occupation } \times \\
\text { change of occupation type }(1=\text { yes })\end{array}$ & $\begin{array}{l}0.057 \\
(0.036)\end{array}$ & $\begin{array}{l}0.007 \\
(0.041)\end{array}$ & $\begin{array}{l}0.123 \\
(0.088)\end{array}$ \\
\hline $\begin{array}{l}\text { Unskilled services } \times \\
\text { change of occupation type }(1=\text { yes })\end{array}$ & $\begin{array}{l}0.121^{* * *} \\
(0.038)\end{array}$ & $\begin{array}{l}0.114^{* * *} \\
(0.043)\end{array}$ & $\begin{array}{l}0.164^{*} \\
(0.089)\end{array}$ \\
\hline $\begin{array}{l}\text { Skilled services } \times \text { of } \\
\text { change occupation type }(1=\text { yes })\end{array}$ & $\begin{array}{l}0.241^{* * *} \\
(0.052)\end{array}$ & $\begin{array}{l}0.219^{* * *} \\
(0.053)\end{array}$ & $\begin{array}{l}0.496^{* * *} \\
(0.126)\end{array}$ \\
\hline $\begin{array}{l}\text { Unskilled comm. and admin. occ. } \times \\
\text { change of occupation type }(1=\text { yes })\end{array}$ & $\begin{array}{l}0.139^{* * *} \\
(0.042)\end{array}$ & $\begin{array}{l}0.129^{* * *} \\
(0.043)\end{array}$ & $\begin{array}{l}0.181 \\
(0.115)\end{array}$ \\
\hline $\begin{array}{l}\text { Semi-professions } \times \text { change } \\
\text { of occupation type }(1=\text { yes })\end{array}$ & $\begin{array}{l}-0.014 \\
(0.061)\end{array}$ & $\begin{array}{l}0.017 \\
(0.066)\end{array}$ & $\begin{array}{l}-0.173 \\
(0.122)\end{array}$ \\
\hline Number of observations & 16,133 & 11,789 & 4,344 \\
\hline \multicolumn{4}{|l|}{ Selection equation } \\
\hline $\begin{array}{l}\text { Regional unemployment rate in June } \\
1997\end{array}$ & $\begin{array}{l}0.001 \\
(0.001)\end{array}$ & $\begin{array}{l}-0.001 \\
(0.001)\end{array}$ & $\begin{array}{l}0.004^{* * *} \\
(0.001)\end{array}$ \\
\hline $\begin{array}{l}\text { Low-wage employment in } 1997 \\
\text { (1= yes) }\end{array}$ & $\begin{array}{l}0.433^{* * *} \\
(0.004)\end{array}$ & $\begin{array}{l}0.453^{* * *} \\
(0.005)\end{array}$ & $\begin{array}{l}0.381^{* * *} \\
(0.007)\end{array}$ \\
\hline $\begin{array}{l}\text { Years of work experience between } \\
\text { 1993-1997 }\end{array}$ & $\begin{array}{l}-0.062^{* * *} \\
(0.002)\end{array}$ & $\begin{array}{l}-0.064^{* * *} \\
(0.002)\end{array}$ & $\begin{array}{l}-0.054^{* * *} \\
(0.003)\end{array}$ \\
\hline $\begin{array}{l}\text { Part-time/marginal employed in } 1997 \\
\text { (1=yes) }\end{array}$ & $\begin{array}{l}0.310^{* * *} \\
(0.010)\end{array}$ & $\begin{array}{l}0.335^{* * *} \\
(0.010)\end{array}$ & $\begin{array}{l}0.242^{* * *} \\
(0.021)\end{array}$ \\
\hline Number of observations & 236,750 & 88,588 & 148,162 \\
\hline$\rho$ (correlation of the error terms) & $0.169^{* * *}$ & $0.120^{* * *}$ & $0.242^{* * *}$ \\
\hline
\end{tabular}


Table 6 Continued

\begin{tabular}{|c|c|c|c|}
\hline \multirow[t]{2}{*}{ Independent variables } & \multicolumn{3}{|c|}{ Still full-time employed workers } \\
\hline & Women and men & Women & Men \\
\hline Significance of the model & $\begin{array}{l}\chi 2(55)= \\
2002.0^{* * *}\end{array}$ & $\begin{array}{l}\chi^{2}(53)= \\
1241.3^{* * *}\end{array}$ & $\begin{array}{l}\chi 2(53)= \\
714.0^{* * *}\end{array}$ \\
\hline Joint significance of variable groups & $\begin{array}{l}\text { Age }^{* * *}, \text { level of } \\
\text { education***, type } \\
\text { of occupation***, } \\
\text { plant size***, age } \\
\text { composition of } \\
\text { workers in the } \\
\text { plant n.s., } \\
\text { industry**, } \\
\text { plant size } \times \\
\text { change of plant n.s., } \\
\text { occupation type } \times \\
\text { change of occupa- } \\
\text { tion type }\end{array}$ & $\begin{array}{l}\text { Age } e^{* * *}, \text { level of } \\
\text { education } \\
\text { of occupation , type } \\
\text { plant size } \\
\text { composition of } \\
\text { workers in the } \\
\text { plant n.s., } \\
\text { industry***, } \\
\text { plant size } \times \\
\text { change of plant n.s., } \\
\text { occupation type } \times \\
\text { change of occupa- } \\
\text { tion type }\end{array}$ & $\begin{array}{l}\text { Age } \text { e** }^{* *} \text { level of } \\
\text { education*, type } \\
\text { of occupation**, } \\
\text { plant size*, age } \\
\text { composition of } \\
\text { workers in the } \\
\text { plant n.s., } \\
\text { industry n.s., plant } \\
\text { size } \times \text { change } \\
\text { of plant**, } \\
\text { occupation type } \times \\
\text { change of occupa- } \\
\text { tion type*** }\end{array}$ \\
\hline
\end{tabular}

Notes: own calculations based on BAP. Marginal effects calculated at the sample mean. Heteroscedasticityconsistent standard errors in parentheses (clustered at plant level). 16 industry dummies suppressed in the table. Reference categories of dummy variable groups: age 35-49, secondary school certificate with vocational training, skilled commercial and administrative occupations, 1-20 employees, percentage of workers aged 35-49. Significance levels: ${ }^{*} p<0.1{ }^{* *} p<0.05 ;{ }^{* *} p<0.01$; n.s. denotes statistical insignificance. The selection equation contains all variables from the upward mobility equation, except change of plant, change of occupation type and interactions with these variables.

500 employees a change of plants is relatively less successful than in smaller plants. This implies that staying in small plants is a risky strategy for low-wage earners. ${ }^{11}$

Finally, while changing occupations may in general be helpful in leaving the low-wage sector (see Tables 4 and 5), it is not easy to disentangle which occupations are most detrimental to upward wage mobility. The results in Table 6 show that (compared to the reference group of skilled commercial and administrative occupations) the chance of leaving the low-wage sector is particularly low when staying in unskilled and skilled service occupations and in unskilled commercial and administrative occupations. ${ }^{12}$ Moreover, the interaction effects suggest that in these three occupational categories a change of occupation is relatively more successful in terms of upward wage mobility. In order to draw more specific conclusions, however, more detailed data must be used, which in turn would complicate the estimation and interpretation even more. ${ }^{13}$

\footnotetext{
${ }^{11}$ While this analysis includes only information on the plants in which lowwage earners were employed initially, Schank et al. (2009) also take into account the characteristics of the plants to which individuals move. They show that moving to a large plant is associated with the highest probability of upward wage mobility.

${ }^{12}$ We exclude individuals whose occupation is unknown in the regressions of Table 6. Interactions of the variable "occupation type unknown" with other variables resulted in estimation problems due to the small number of observations in cells related to this variable.

${ }^{13}$ In order not to complicate matters further and to avoid problems of insufficient numbers of observations in certain cells, we have refrained from
}

\section{Conclusions}

Using representative linked employer-employee data of the German Federal Employment Agency, this paper has investigated the extent to which full-time employees who earned low wages (i.e. less than two-thirds of the median wage) in 1998/99 were able to earn higher wages in the following years, and which factors played a role in this context. We have shown that just one out of seven of these lowwage earners received wages above the low-wage threshold in 2003. While upward wage mobility thus appears to be limited, low-wage employment is not a persistent experience or a dead end for all low-wage earners. Bivariate probit analyses with endogenous selection indicate that younger and better qualified low-wage earners record a higher probability of getting higher-paid employment, whereas women are substantially less successful.

While the relevance of these individual characteristics has also been found in previous studies, the main focus of our analysis has been to check whether there exist firms and/or occupations that prove to be dead ends for low-wage workers. We have shown that the characteristics of the employing firm indeed matter for low-wage earners' probability of escaping low-paid work. In particular, plants with a high share of low-wage earners seem to be dead ends for individual low-wage earners since there, the chance of upward

also interacting the plant change and the occupation change dummies with each other and cross-wise with occupations and plant size. 
wage mobility is significantly lower. In contrast, plants with high shares of women or of foreigners do not reduce the upward wage mobility of women and foreigners, respectively. Another dead end for low-wage earners seems to be small plants, which offer significantly lower chances of upward wage mobility than larger plants. The likelihood of leaving the low-wage sector is also particularly low when staying in unskilled and skilled service occupations and in unskilled commercial and administrative occupations. Consequently, leaving these dead-end plants and occupations appears to be an important instrument for achieving wages above the lowwage threshold.

Although we have not analyzed the extent to which wages rose above the low-wage threshold and how permanent such a rise was, our results indicate that low-wage employment can be a stepping stone into better-paid jobs for some employees. At the same time, staying in the "wrong" kind of firm or occupation can make low-wage employment persistent. The matching of employees to firms in the low-wage sector thus may have important and long-lasting effects on the wage and employment careers of these workers. As also suggested by Andersson et al. (2005, p. 13), labour market policies that seek to improve the access of low-wage earners to higher-wage firms and occupations could have substantial payoffs. While subsidizing low-wage work is one way of lifting employees' income to decent levels, it may be better to place these low-wage earners in firms and jobs that enable them to leave the low-wage trap on their own initiative.

\section{Executive summary}

In recent years the low-wage sector has expanded considerably in Germany. In 2005 about $18 \%$ of full-time employees covered by social insurance earned low wages. There is an ongoing political debate concerning the growing lowwage sector and it is not clear whether this development is beneficial. On the one hand, the creation of low-wage jobs contributes to the reduction of unemployment. On the other hand it leads to higher wage inequality, and working conditions of low-wage workers are often bad. Hence, it is important to know whether episodes of low-wage employment are persistent or transitory events for low-wage workers. Are there individual characteristics or obstacles in their working environment that hinder employees from leaving the lowwage sector?

This paper analyzes the determinants of upward mobility of low-wage workers in Germany. Following the literature, we define an individual as low-paid if he or she earns less than two thirds of the median wage of full-time employees covered by social insurance. We use representative linked employer-employee data of the Federal Employment
Agency in order to study the upward wage mobility of individuals who earned low wages in the years 1998 and 1999. Bivariate probit models which account for the selection into low-wage employment identify the characteristics that lead to upward mobility. While individual determinants have been investigated in several international studies, this study focuses on the impact of firm characteristics and of occupations. Moreover, we analyze whether there are dead-end firms or dead-end jobs for low-wage earners.

We find that just one out of seven workers who earned low wages in 1998 and 1999 received wages above the low-wage threshold in 2003. While upward wage mobility thus appears to be limited, low-wage employment is not a persistent experience or a dead-end for all low-wage earners. Upward mobility is more likely for younger and better qualified low-wage earners and for men. In particular, firm characteristics turn out to be important determinants of upward mobility. Plants with a high share of low-wage earners and small plants often seem to be dead-ends. Upward mobility in these plants is limited, and changing the plant goes along with an increased upward mobility. The likelihood of leaving the low-wage sector is also particularly low when staying in unskilled and skilled service occupations and in unskilled commercial and administrative occupations. In contrast, the shares of women and foreigners in the plant do not have significant impacts on upward mobility.

To sum up, low-wage jobs are not always dead-end jobs. However staying in the "wrong" kind of firm or occupation can make low-wage employment persistent. Labour market policies that seek to improve the access of low-wage earners to higher-wage firms and occupations could have substantial payoffs.

\section{Kurzfassung}

Der Anteil von Geringverdienern am deutschen Arbeitsmarkt ist in den vergangenen Jahren stark gestiegen. 2005 waren ca. $18 \%$ aller sozialversicherungspflichtig Vollzeitbeschäftigten im Niedriglohnsektor tätig. In der politischen Diskussion wird die Ausweitung des Niedriglohnsektors ambivalent betrachtet. Einerseits trägt die Schaffung von niedrig bezahlten Arbeitsplätzen zur Reduktion der Arbeitslosigkeit bei. Andererseits werden die wachsende Lohnungleichheit und die schlechten Arbeitsbedingungen für Geringverdiener kritisch gesehen. Wichtig zu wissen ist hierbei, ob Beschäftigte dauerhaft im Niedriglohnbereich verweilen oder ob den Betroffenen ein Aufstieg in besser bezahlte Beschäftigung gelingt. Gibt es individuelle Charakteristika oder Bedingungen im Arbeitsumfeld von Geringverdienern, die den Aufstieg aus der Niedriglohnbeschäftigung behindern? 
Dieser Artikel analysiert die Determinanten des Aufstiegs aus der Niedriglohnbeschäftigung in Deutschland. Zur Definition von Niedriglohnbeschäftigung verwenden wir eine in der einschlägigen Literatur übliche Definition: Als niedriglohnbeschäftigt gilt, wer weniger als zwei Drittel des Medianlohns aller sozialversicherungspflichtig Vollzeitbeschäftigten verdient. Wir nutzen repräsentative verbundene Arbeitnehmer-Arbeitgeber-Daten der Bundesagentur für Arbeit, um die Aufwärtsmobilität von sozialversicherungspflichtig Vollzeitbeschäftigten zu untersuchen, die in den Jahren 1998 und 1999 Geringverdiener waren. Mit bivariaten Probitmodellen, die die Selektion von Beschäftigten in die Niedriglohnbeschäftigung berücksichtigen, bestimmen wir, welche Eigenschaften den Aufstieg in den Hochlohnbereich begünstigen. Die Rolle von individuellen Eigenschaften für die Aufstiegschancen wurde schon in einigen internationalen Studien erforscht. Der Fokus dieser Analyse liegt daher auf dem Einfluss von betrieblichen Charakteristika und von Berufen auf die Aufwärtsmobilität von Geringverdienern. Zudem untersuchen wir, ob es bestimmte Betriebe oder Berufe gibt, die Sackgassen für Niedriglohnbeschäftigte darstellen.

Es zeigt sich, dass lediglich einer von sieben Beschäftigten, die 1998 und 1999 Geringverdiener waren, im Jahr 2003 einen Lohn erhielt, der über der Niedriglohnschwelle lag.
Niedriglohnbeschäftigung ist also nicht persistent, jedoch ist die Aufwärtsmobilität von Geringverdienern begrenzt. Im Hinblick auf individuelle Charakteristika ergibt sich, dass jüngere, besser qualifizierte und männliche Geringverdiener höhere Aufstiegschancen haben. Insbesondere betriebliche Charakteristika stellen sich als bedeutende Determinanten der Aufwärtsmobilität heraus. So erweisen sich Betriebe mit einem hohen Anteil von Geringverdienern und kleine Betriebe oft als Sackgassen. Die Aufwärtsmobilität in diesen Betrieben ist gering und insbesondere bei einer Beschäftigung in solchen Betrieben geht ein Betriebswechsel mit einer erhöhten Aufstiegswahrscheinlichkeit einher. Hingegen haben die Anteile von Frauen und Ausländern in den Betrieben keinen signifikanten Einfluss auf die Aufwärtsmobilität. Die Aufstiegschancen sind zudem gering, wenn man in Dienstleistungsberufen oder in niedrig qualifizierten kaufmännischen oder Verwaltungsberufen verharrt.

Es lässt sich festhalten, dass eine Niedriglohnbeschäftigung nicht immer eine Sackgasse ist. Jedoch sind der ausgeübte Beruf und bestimmte betriebliche Charakteristika offenbar entscheidend für die Chancen, in besser bezahlte Jobs aufzusteigen. Für die Arbeitsmarktpolitik wären deshalb möglicherweise Maßnahmen lohnenswert, die den Zugang von Geringverdienern zu Firmen mit günstigen Charakteristika und zu qualifizierten Berufen erleichtern.

\section{Appendix}

Table 7 Summary statistics of variables in the sample

\begin{tabular}{|c|c|c|c|}
\hline Variable & Obs. & Mean & Std. Dev. \\
\hline \multicolumn{4}{|l|}{ Multi-year low-wage workers } \\
\hline Female $(1=$ yes $)$ & 28,184 & 0.728 & 0.445 \\
\hline Age $15-24(1=$ yes $)$ & 28,184 & 0.138 & 0.345 \\
\hline Age $25-34(1=$ yes $)$ & 28,184 & 0.277 & 0.447 \\
\hline Age $35-49(1=$ yes $)$ & 28,184 & 0.434 & 0.496 \\
\hline Age $50-57(1=$ yes $)$ & 28,184 & 0.152 & 0.359 \\
\hline School leaving certificate without vocational training $(1=$ yes $)$ & 28,184 & 0.192 & 0.394 \\
\hline Secondary school certificate with vocational training $(1=$ yes $)$ & 28,184 & 0.614 & 0.487 \\
\hline High school certificate with vocational training $(1=$ yes $)$ & 28,184 & 0.013 & 0.111 \\
\hline University degree $(1=$ yes $)$ & 28,184 & 0.006 & 0.079 \\
\hline Education unknown $(1=$ yes $)$ & 28,184 & 0.176 & 0.380 \\
\hline Foreigner $(1=$ yes $)$ & 28,173 & 0.100 & 0.300 \\
\hline Unskilled manual occupations $(1=$ yes $)$ & 28,184 & 0.189 & 0.391 \\
\hline Skilled manual occupations $(1=$ yes $)$ & 28,184 & 0.125 & 0.331 \\
\hline Unskilled services $(1=$ yes $)$ & 28,184 & 0.209 & 0.407 \\
\hline Skilled services $(1=$ yes $)$ & 28,184 & 0.130 & 0.336 \\
\hline Unskilled commercial and administrative occupations ( $1=$ yes $)$ & 28,184 & 0.155 & 0.362 \\
\hline Skilled commercial and administrative occupations $(1=$ yes $)$ & 28,184 & 0.166 & 0.372 \\
\hline Semi-professions $(1=$ yes $)$ & 28,184 & 0.023 & 0.149 \\
\hline Occupation type unknown $(1=$ yes $)$ & 28,184 & 0.003 & 0.058 \\
\hline Plant with $1-20$ employees $(1=$ yes $)$ & 28,184 & 0.584 & 0.493 \\
\hline
\end{tabular}


Tabelle 7 Continued

\begin{tabular}{|c|c|c|c|}
\hline Variable & Obs. & Mean & Std. Dev. \\
\hline Plant with $21-100$ employees ( $1=$ yes $)$ & 28,184 & 0.249 & 0.433 \\
\hline Plant with $101-500$ employees $(1=$ yes $)$ & 28,184 & 0.137 & 0.344 \\
\hline Plant with more than 500 employees $(1=$ yes $)$ & 28,184 & 0.029 & 0.169 \\
\hline Percentage of women in the plant & 28,184 & 60.439 & 31.586 \\
\hline Percentage of highly-qualified workers in the plant & 26,710 & 4.989 & 12.555 \\
\hline Percentage of workers aged $15-24$ in the plant & 28,184 & 16.428 & 17.370 \\
\hline Percentage of workers aged $25-34$ in the plant & 28,184 & 26.830 & 19.047 \\
\hline Percentage of workers aged $35-49$ in the plant & 28,184 & 37.483 & 21.123 \\
\hline Percentage of workers older than 49 years in the plant & 28,184 & 19.259 & 18.472 \\
\hline Percentage of low-wage workers in the plant & 28,111 & 63.767 & 31.971 \\
\hline Percentage of foreign workers in the plant & 28,111 & 8.948 & 19.590 \\
\hline Plant located in eastern Germany $(1=$ yes $)$ & 28,184 & 0.232 & 0.422 \\
\hline Change of plant $(1=$ yes $)$ & 20,327 & 0.400 & 0.490 \\
\hline Change of occupation type $(1=$ yes $)$ & 28,184 & 0.415 & 0.493 \\
\hline $1-20$ employees $\times$ change of plant $(1=$ yes $)$ & 20,327 & 0.234 & 0.423 \\
\hline $21-100$ employees $\times$ change of plant $(1=$ yes $)$ & 20,327 & 0.103 & 0.304 \\
\hline $101-500$ employees $\times$ change of plant $(1=$ yes $)$ & 20,327 & 0.054 & 0.225 \\
\hline More than 500 employees $\times$ change of plant $(1=$ yes $)$ & 20,327 & 0.009 & 0.097 \\
\hline Percentage of low-paid workers $\times$ change of plant $(1=$ yes $)$ & 20,283 & 26.576 & 37.885 \\
\hline Unskilled manual occupations $\times$ change of occupation type $(1=$ yes $)$ & 28,184 & 0.084 & 0.277 \\
\hline Skilled manual occupations $\times$ change of occupation type $(1=$ yes $)$ & 28,184 & 0.063 & 0.242 \\
\hline Unskilled services $\times$ change of occupation type $(1=$ yes $)$ & 28,184 & 0.092 & 0.290 \\
\hline Skilled services $\times$ change of occupation type $(1=$ yes $)$ & 28,184 & 0.045 & 0.207 \\
\hline Unskilled comm. and admin. occupations $\times$ change of occ. type $(1=$ yes $)$ & 28,184 & 0.064 & 0.244 \\
\hline Skilled comm. and admin. occupations $\times$ change of occ. type $(1=$ yes $)$ & 28,184 & 0.058 & 0.233 \\
\hline Semi-professions $\times$ change of occupation type $(1=$ yes $)$ & 28,184 & 0.009 & 0.092 \\
\hline \multicolumn{4}{|l|}{ All full-time workers 1998/99 } \\
\hline Regional unemployment rate in June 1997 & 241,354 & 12.212 & 4.287 \\
\hline Low-wage employment in $1997(1=$ yes $)$ & 241,742 & 0.120 & 0.325 \\
\hline Years of work experience between 1993-1997 & 241,742 & 4.336 & 1.165 \\
\hline Part-time/marginal employed in $1997(1=$ yes $)$ & 241,742 & 0.021 & 0.145 \\
\hline
\end{tabular}

\section{References}

Achatz, J., Gartner, H., Glück, T.: Bonus oder Bias? Mechanismen geschlechtsspezifischer Entlohnung. Kölner Z. Soziol. Soz. 57(3), 466-493 (2005)

Ai, C., Norton, E.: Interaction terms in logit and probit models. Econ. Lett. 80, 123-129 (2003)

Andersson, F., Holzer, H.J., Lane, J.I.: Moving up or Moving on: Who Advances in the Low-Wage Labor Market? Russell Sage Foundation Publications, New York (2005)

Asplund, R., Sloane, P.J., Theodossiou, I. (eds.): Low Pay and Earnings Mobility in Europe. Edward Elgar Publishing, Cheltenham (1998)

Blossfeld, H.-P.: Labor-market entry and the sexual segregation of careers in the Federal Republic of Germany. Am. J. Sociol. 93(1), 89-118 (1987)

Bolvig, I.: Within- and between-firm mobility in the low-wage labour market. In: Bazen, S., Lucifora, C., Salverda, W. (eds.) Job Quality and Employer Behaviour, pp. 132-156. Basingstoke, New York (2005)

Bosch, G., Kalina, T.: Low-wage work in Germany: an overview. In: Bosch, G., Weinkopf, C. (eds.) Low-Wage Work in Germany, pp. 19-112. Russell Sage Foundation Publications, New York (2008)
Cahuc, P., Zylberberg, A.: Labor Economics. The MIT Press, Cambridge, Mass (2004)

Cappellari, L.: Do the "working poor" stay poor? An analysis of low pay transitions in Italy. Oxford B. Econ. Stat. 64(2), 87-110 (2002)

Cappellari, L.: Earnings mobility among Italian low-paid workers. J. Popul. Econ. 20(2), 465-482 (2007)

Cappellari, L., Jenkins, S.: Modelling low pay transition probabilities, accounting for panel attrition, nonresponse and initial conditions. J. R. Stat. Soc. Ser. C 57(2), 165-186 (2008)

Deding, M.C.: Low Wage Mobility in Denmark, Germany and the United States. Working Paper 33:2002. The Danish National Institute of Social Research, Copenhagen (2002)

Eichhorst, W., Gartner, H., Krug, G., Rhein, T., Wiedemann, E.: Niedriglohnbeschäftigung in Deutschland und im internationalen Vergleich, in: Allmendinger, J., Eichhorst, W., Walwei, U. (eds.) IAB Handbuch Arbeitsmarkt - Analysen, Daten, Fakten, pp. 107-142. Campus Verlag, Frankfurt am Main (2005)

European Commission: Labour market transitions and advancement: temporary employment and low-pay in Europe. In: European Commission (ed.) Employment in Europe 2004, pp. 159-186. Luxemburg (2004)

Gerner, H.-D., Stegmaier, J.: Unsicherheit und betriebliche Weiterbildung: Eine empirische Analyse der Weiterbildungsaktivität 
unter Unsicherheit in KMU und Großbetrieben. Diskussionspapier Nr. 58, Lehrstuhl für Arbeitsmarkt- und Regionalpolitik, Universität Erlangen-Nürnberg (2008)

Görzig, B., Gornig, M., Werwatz, A.: Ostdeutschland: Strukturelle Niedriglohnregion? DIW Wochenber. 71(44), 685-691 (2004)

Grün, C., Lutz, H., Mahringer, H., Rhein, T.: Being low paid: springboard or dead end? Paper presented at the Annual Conference of the Verein für Socialpolitik in Magdeburg, 8-11 September, 2009 (2009)

Heckman, J.J.: The incidental parameters problem and the problem of initial conditions in estimating a discrete time-discrete data stochastic process, in: Manski, C.F., McFadden, D. (eds.) Structural Analysis of Discrete Data with Econometric Applications, pp. 179-195. The MIT Press, Cambridge (1981)

Jung, S., Schnabel, C.: Paying more than necessary? The wage cushion in Germany. Discussion Paper No. 63, Lehrstuhl für Arbeitsmarkt- und Regionalpolitik, Universität Erlangen-Nürnberg (2009)

Klein-Schneider, H. (ed.): Interner Arbeitsmarkt: Beschäftigung und Personalentwicklung in Unternehmen und Verwaltungen. Bund Verlag, Frankfurt am Main (2003)

Koch, I., Meinken, H.: The employment panel of the German Federal Employment Agency. J. Appl. Soc. Sci. Stud. 124(2), 315-325 (2004)

Manning, A.: Monopsony in Motion: Imperfect Competition in Labor Markets. Princeton University Press, Princeton (2003)

Nienhüser, W.: Ursachen und Wirkungen betrieblicher Personalstrukturen. Schäffer-Poeschel, Stuttgart (1998)

OECD: Earnings inequality, low-paid employment and earnings mobility. In: OECD (ed.) Employment Outlook 1996, pp. 59-108. Paris (1996)

Pfeffer, J., Davis-Blake, A.: The effect of the proportion of women on salaries: the case of college administrators. Admin. Sci. Quart. 32(1), 1-24 (1987)

Postel-Vinay, F., Robin, F.M.: Equilibrium wage dispersion with worker and employer heterogeneity. Econometrica 70(6), 22952350 (2002)

Rhein, T., Grün, C.: Eine Bestandsaufnahme: Niedriglohnbeschäftigung in Deutschland. IAB-Forum 1, 8-12 (2007)

Rhein, T., Stamm, M.: Niedriglohnbeschäftigung in Deutschland. Deskriptive Befunde zur Entwicklung seit 1980 und Verteilung auf Berufe und Wirtschaftszweige. IAB Forschungsbericht $12 / 2006(2006)$

Schank, T., Schnabel, C., Stephani, J.: Geringverdiener: wem und wie gelingt der Aufstieg? Jahrb. Natl. Stat. 229(5), 584-614 (2009)
Schmucker, A., Seth, S.: BA-Beschäftigtenpanel 1998-2005, Codebuch. FDZ-Datenreport Nr. 5/2006, Nürnberg (2006)

Sloane, P.J., Theodossiou, I.: Methodological and econometric issues in the measurement of low pay and earnings mobility. In: Asplund, R., Sloane, P.J., Theodossiou, I. (eds.) Low Pay and Earnings Mobility in Europe, pp. 3-12. Edward Elgar Publishing, Cheltenham (1998)

Stewart, M.B., Swaffield, J.K.: Low pay dynamics and transition probabilities. Economica 66(1), 23-42 (1999)

Uhlendorff, A.: From No Pay to Low Pay and Back Again? A MultiState Model of Low Pay Dynamics. IZA Discussion Paper No. 2482, Bonn (2006)

Alexander Mosthaf studied social sciences at the University of Erlangen-Nuremberg and at the University of Chile. He has been a researcher at the Institute for Employment Research (IAB) since April 2008 and a doctoral student of the Graduate Programme of the $\mathrm{IAB}$ and the School of Business and Economics of the University of Erlangen-Nuremberg since October 2008.

His research interests include labour market dynamics of low-wage workers.

e-mail: alexander.mosthaf@iab.de

Claus Schnabel studied economics at the University of Kent at Canterbury (M.A. in Economics 1985) and at Hohenheim University (PhD 1988) and finished his habilitation at Ruhr University Bochum in 1997. From 1988 to 2000 he worked as researcher and finally as head of the industrial relations section at the Cologne Institute for Business Research (IW Köln). Since 2000 he has been Professor for Labour and Regional Economics at the Friedrich-Alexander University ErlangenNuremberg.

His main research interests are in the fields of industrial relations, wages, collective bargaining, unions and works councils.

e-mail: claus.schnabel@wiso.uni-erlangen.de

Jens Stephani studied business administration at the Ludwig-Maximilians-University in Munich and economics at the University of Erlangen-Nuremberg (Diploma in Economics 2008). He has been as researcher at the Institute for Employment Research (IAB) since 2008. Since 2009, he has been a doctoral student in the Graduate Programme of the IAB and the School of Business and Economics of the University of Erlangen-Nuremberg.

His research interests include individual, intra-firm and regional aspects of the wage mobility of low-wage workers.

e-mail: jens.stephani@iab.de 